\title{
Ustrojowe i społeczne uwarunkowania lokacji miejskich na ziemiach polskich w 1. połowie XIII wieku*
}

\section{Political and social conditions of urban incorporation in Polish territory in the first half of the $13^{\text {th }}$ century}

Zarys treści. Rozwój badań archeologicznych pokazał wieloetapowość przekształceń osadniczych w centrach miejskich i umożliwił bardziej wnikliwą interpretację dokumentacji pisanej. Model lokacji na prawie niemieckim rozwijał się stopniowo w ciągu XII-XIII wieku: od kolonii obcych kupców, określanych mianem gości (hospites) - do handlowo-rzemieślniczego miasta komunalnego. Model wczesnego miasta na prawie niemieckim pokazuje dokument projektowanej w 1237 roku lokacji Płocka. Trwające dziesiątki lat konflikty z Kościołem pozostawiły w tym mieście dokumentację źródłową, która pozwala na poznanie przebiegu powstawania gminy miejskiej. Podobny proces można obserwować w innych siedzibach diecezji: Wrocławiu, Poznaniu, Gnieźnie, Włocławku i Krakowie. Wszędzie (z wyjątkiem Włocławka) nie rozwinęły się biskupie miasta. Już w pierwszej fazie urbanizacji dążenia książąt do przejęcia korzyści z rozwoju gospodarki pieniężnej zderzały się z uprawnieniami własnościowymi Kościoła. Po wprowadzeniu reform gregoriańskich w Polsce zmalała zależność biskupów od książąt. Uprawnienia własnościowe, niezbędne do wypełniania zadań politycznych przez episkopat i funkcjonowania liturgii, stawały się balastem. Piastowie stopniowo usuwali uprawnienia Kościoła, uprzywilejowując inne dobra biskupie oraz współdziałając z powstającymi gminami miejskimi.

Slowa kluczowe: goście - hospites, miasta biskupie w Polsce, model pierwszej lokacji na prawie niemieckim

1. Gwałtowne przyśpieszenie procesów urbanizacji na ziemiach polskich w 1. połowie XIII wieku nie zostało w sposób równomierny poświadczone w źródłach pisanych. Kształtowanie się sieci ośrodków miejskich przypadło 
bowiem na czasy, kiedy dokument książęcy dopiero stawał się środkiem kontroli obrotu własnością ziemską i generalnie potwierdzania praw majątkowych (Jurek 2011, s. 212 i nn.; 2015, s. 88 i nn.). O pierwszych etapach lokacji mamy jedynie ułamkowe informacje, które przysłania rozwinięty w połowie stulecia ich model. Przekazów pisanych w zasadzie już nie przybywa; co najwyżej potrafimy je lepiej rozumieć i interpretować. Od strony źródłoznawczej problem dodatkowo oświetlają rozwijające się badania nad kulturą piśmienną. Jesteśmy jednak w niemałym stopniu zakładnikami starszych badań analitycznych, których hipotetyczne stwierdzenia i uogólniające konstrukcje są uważane za pewny punkt oparcia dalszych interpretacji. Opinię formułuję na podstawie własnych doświadczeń, ponieważ kilka razy wracałem do postawionego w tytule tematu (Gawlas 2000, s. 26 i nn.; 2005, s. 133-162; 2009, s. 9-28). Niezależnie od tego muszę podkreślić, że w najnowszych badaniach rozwój ośrodków miejskich jest ujmowany w sposób coraz bardziej zindywidualizowany i regionalnie zróżnicowany. Komplikuje to obraz, ale jednocześnie przybliża do rzeczywistości przeszłej. Niniejsze uwagi mają więc charakter refleksji nad nowszym stanem badań.

Szczególne wartościowe ustalenia materiałowe przyniosły prace związane z przygotowywaniem spisów urzędników miejskich z obszaru dawnej Rzeczypospolitej, Śląska i Pomorza Zachodniego ${ }^{1}$. Wymusiły one dla „większości badanych miast, niespotykaną wcześniej szczegółowość refleksji nad strukturą i funkcjonowaniem instytucji komunalnych, przynosząc w efekcie godny podkreślenia postęp w poznaniu dziejów lokalnych" (Goliński 2013, s. 5). Ustrojowe wstępy w opublikowanych dotychczas spisach i zbiorowy tom studiów (Organizacja władz miejskich 2013) zawierają bardzo dobrą dokumentację różnych wariantów organizacji władz miejskich i ich przemian. W odniesieniu do pierwszej fazy lokacji analizy napotykają jednak na wspomnianą barierę źródłową. Dotyczy ona również międzynarodowych badań prawno-historycznych nad funkcjonowaniem praw miejskich na obszarze kolonizacji niemieckiej (Lück 2009, s. 163-181²). Spalenie w 1631 roku archiwum Magdeburga spowodowało, że w tego typu badaniach wielkie znaczenie mają właśnie źródła pochodzące z ziem polskich, w tym: przekazany w 1211 roku do Złotoryi odpis przywileju arcybiskupa Wichmanna z 1188 roku, pouczenia prawne dla Środy Śląskiej z 1235 roku, czy Wrocławia 1261 i 1295 roku (Magdeburger Recht 1989; Magdeburg 2005, s. 137-153), także przywilej chełmiński z 1233 roku. Można dodać, że wysoki stopień precyzji i wnikliwości osiągnęła analiza planistyczno-miernicza lokacyjnych układów urbanistycznych (Krasnowolski 2004; 2006, s. 65-137; Maciakowska 2011). Wspierają je badania architektoniczno-konserwatorskie - na przykład ostatnia

\footnotetext{
${ }^{1}$ Ostatnio t. 1: Śląs, z. 3: Nysa; por. Wółkiewicz 2013.

2 Por. także inne artykuły w tomie oraz przegląd stanu badań: Europejskie miasta 2007; Rechtsund Sprachtransfer 2008.
} 
monografia o świdnickiej kamienicy mieszczańskiej (Chorowska, Lasota 2013). Wspomnieć też należy o postępujących pracach nad atlasami historycznymi miast.

Zasadniczy przełom przyniosły badania archeologiczne, które pokazały długotrwałość i wieloetapowość przekształceń osadniczych w centrach miejskich. Ich rezultaty bardzo zmieniły sposób patrzenia na początki urbanizacji, ponieważ lepiej rozumiemy ewolucyjność tego procesu ${ }^{3}$. Lista ośrodków, które mają syntetycznie opracowaną dokumentację w sposób dostępny dla historyków oraz duże znaczenie jest bardzo długa: Kraków (Kraków w chrześcijańskiej Europie 2006; Kraków europejskie miasto 2007; Kraków 2014)4, Poznań (Civitas Posnaniensis 2005), Lublin (Rozwałka, Niedźwiadek, Stasiak 2006), Przemyśl (Przemyśl 2010), Płock (Wczesnośredniowieczny Płock 2002; Płock 2011), Gdańsk (Archeologia Gdańska 2006a; 2006b; 2007; 2010; 2013a; 2013b), Elbląg (Nawrolska 2012), Kołobrzeg (Kołobrzeg 2007), Szczecin (Kowalska, Dworaczek 2011). Nie jest moim zadaniem podjęcie próby pełniejszego zebrania ich wyników, z góry zresztą skazanej na niepowodzenie ${ }^{5}$. W tym miejscu odwołuję się przede wszystkim do badań nad Wrocławiem ${ }^{6}$, ze względu na jego pionierskie znaczenie w czasie powstawania modelu lokacji i szczególne bogactwo materiałów. Trzeba podkreślić, że współpraca archeologów z historykami i wykorzystanie źródeł pisanych układa się bardzo dobrze właśnie w ramach badań poszczególnych miast. Gorzej jest na płaszczyźnie wyobrażeń o uwarunkowaniach społeczno-gospodarczych i ustrojowych. Na interpretacje archeologów mocno oddziałują tradycyjne ujęcia podręcznikowe, w tym zwłaszcza koncepcja ustroju prawa książęcego (Moździoch 2002). Dostrzegam w tej sytuacji ważną przeszkodę w pełnym wykorzystaniu rezultatów ich badań.

Na osobną uwagę zasługuje ogromny i krytycznie przepracowany materiał porównawczy w książce Marka Słonia o miastach podwójnych (a nierzadko wielokrotnych) w łacińskiej Europie - od Prowansji i Langwedocji po zakonne Prusy (Słoń 2010). Jej znaczenie trudno przecenić. Nie wywołała ona jednak szerszej dyskusji, na którą niewątpliwie zasługuje. Autor konsekwentnie dąży do nadania rozważaniom stricte analitycznego charakteru, wnika w dyskusje regionalnej literatury i stara się rozstrzygać jej spory, ale ściśle trzyma się założeń dotyczących przedmiotu analiz, którym jest zjawisko powstawania obok siebie

$3 \mathrm{~W}$ poniższych uwagach przytaczam jedynie wybór najnowszych prac o ogólniejszym charakterze (Piekalski 1999; 2004; Rębkowski 2001). Już po ich napisaniu ukazała się książka Jerzego Piekalskiego pt. „Praga, Wrocław i Kraków. Przestrzeń publiczna i prywatna w czasach średniowiecznego przełomu” (2014).

4 Także artykuły w czasopiśmie Krzysztofory, t. 26 (2008) i t. 28, cz. 1-2 (2010).

5 Tom pt. „Stan badań archeologicznych miast w Polsce” (Stan badań 2009) zawiera artykuły przedstawiające rezultaty badań w Gdańsku, a także w innych miastach, dotyczą one głównie późnego średniowiecza. Por. też Civitates principales 1998; Salsa Cholbergensis 2000; Civitas Cholbergensis 2005; Archeologia et historia 2004, Archaeology in a town 2012.

6 Tomy 1-21 serii „Wratislavia antiqua. Studia z dziejów Wrocławia”, niżej przytaczam tytuły bezpośrednio wykorzystanych tomów. 
odrębnych miast komunalnych. Głównym przedmiotem rozważań są: okoliczności i regionalne uwarunkowania ich zakładania, cele władzy zwierzchniej, funkcje ośrodków, relacje między gminami, ich specjalizacje, spory, czynniki sprzyjające unifikacji i stojące przed nią przeszkody. Kryterium decydującym o uwzględnieniu w analizie ośrodka określanego w źródłach jako nova civitas (lub przez ich odpowiedniki w języku niemieckim i innych narodowych) było wykształcenie się instytucji samorządowych, a także odrębnego poczucia tożsamości. Pominięte lub potraktowane marginalnie zostały sytuacje, kiedy nowym miastem nazywano powiększoną część starego miasta. Przy tak szeroko zakrojonej kwerendzie trudno o pełną konsekwencję, ale z pola obserwacji wyeliminowana została znaczna część zjawisk zaistniałych przed powstaniem miast komunalnych. Uwzględnienie terminu villa forensis i jego odpowiedników mogło w istotny sposób wzbogacić analizę. Książka jest obszerna, nie jest to więc zarzut, a jedynie stwierdzenie, że w pracy jest stosunkowo mało materiału dotyczącego problemów przedkomunalnej fazy rozwoju miast. $Z$ tego punktu widzenia najważniejszym osiągnięciem autora jest pokazanie modelu „,nowych miast” tkackich na Śląsku i jego pochodzenia oraz roli lokacji nowych miast jako etapu rozwoju dużych miast na obszarze Meklemburgii i Pomorza Przedniego.

2. Przechodząc do problemu uwarunkowań ustrojowych muszę rozpocząć od zrelatywizowania, bardzo zakorzenionego w badaniach i opornego na zmiany, przeciwstawiania tzw. ustroju prawa książęcego i prawa niemieckiego. Miały one wspólne korzenie w pośredniczącej roli niemieckiego władztwa terytorialnego. Wskazuję od dawna na stojące za tym przeciwstawieniem interpretacyjne schematy i na płaszczyźnie porównawczej staram się pokazać związane z nim jaskrawe anachronizmy, ostatnio na przykładzie badań nad ludnością chłopską (Gawlas 2012, s. 28). Kwestionuję w związku z tym realne istnienie organizacji służebnej i koncepcję praw grupowych. Uważam je za konstrukcje historiograficzne, a nazwy służebne interpretuję jako pozostałość wielkiej własności ziemskiej, która była podstawową formą organizacji zaplecza ekonomicznego książąt, Kościoła i możnych. Nie odpowiada ówczesnej rzeczywistości obraz wszechogarniającego systemu danin prawa polskiego, egzekwowanych przez państwowy aparat terytorialnego zarządu; jest on rekonstruowany na podstawie wykazów zwolnień i ulg w klauzulach przywilejów immunitetowych. Ich listy są jednak tylko w części dokumentacją istniejącego wówczas systemu świadczeń. Przede wszystkim odbijają one rosnącą w ciągu XIII wieku prawniczą akrybię ze strony obdarowywanych instytucji kościelnych, mającą zabezpieczyć ich prawa własnościowe.

W rozważaniach nad funkcjami centralnymi organizacji grodowej nie należy wykorzystywać tradycyjnego obrazu organizacji kasztelańskiej jako, rzekomo niemal niezmiennego, administracyjnego aparatu zarządu kraju i narzędzia zbiorowej eksploatacji ludności chłopskiej. W XII wieku, a zwłaszcza w ostatnich 
dziesięcioleciach tego stulecia, doszło na ziemiach polskich do adaptacji, rozwijających się w tym czasie w Europie Zachodniej, nowych zasad organizacji władzy terytorialnej (Gawlas 2013, s. 273-308). Wśród różnych czynników oddziałujących na wzrost jej prerogatyw dwa były najważniejsze: wyodrębnianie się wyższego sądownictwa oraz sprecyzowanie koncepcji regaliów w trakcie sporu o inwestyturę i pod wpływem recepcji prawa rzymskiego. Publiczna kryminalizacja ciężkich przestępstw powstała w oparciu o ruch pokojów bożych, przekształconych w XII wieku w ustawodawstwo landfrydów (Garnier 2013, s. 235-253; Gawlas 2013, s. 285). Władza monarsza zaczęła w sposób bardziej niż dotychczas rygorystyczny egzekwować swoje sądowe uprawnienia. Rigor iustitiae zastąpił sądownictwo polubowne (Broekmann 2005). Został on bardzo plastycznie opisany przez Wincentego Kadłubka w jego Kronice, przy okazji małopolskich rządów Mieszka Starego (Gawlas 2000, s. 79-81; 2013, s. 285 i nn.). Ich obraz przedstawiony został w krzywym zwierciadle, ale jest egzemplifikacją dokonujących się w tym czasie przemian podstaw władzy. Piastowie rezerwowali dla siebie wyższe, czyli krwawe sądownictwo. Ich narzędziem stali się od początku XIII wieku kasztelanowie, najpierw na Śląsku, wkrótce na innych ziemiach polskich. W Anglii i Francji dopiero w ostatniej ćwierci XII wieku pojawili się urzędnicy zarządu terytorialnego o delegowanej przez panującego władzy. Polscy kasztelanowie nie mieli jeszcze takiego w pełni rozwiniętego urzędniczego charakteru i zapewne adaptowali wzory wschodnioniemieckich burgrabstw (Boshof 2007, s. 103 i nn.; Thieme 2001; Gawlas 2013, s. 294 i nn.; ostatnio Pauk, Wółkiewicz 2012, s. 56 nn.; 2013, s. 69 i nn.). Książętom piastowskim udało się jednak bardzo opóźnić recepcję (częściowo całkiem jej zapobiec) podstawowego dla łacińskiej Europy modelu życia arystokracji - w zamkach i otoczeniu lennej klienteli.

Ustrój tzw. prawa książęcego rozwinął się paralelnie do początków urbanizacji. Wzmocnienie władzy terytorialnej Piastów i ich dążenie do komercjalizacji dochodów wywarło bardzo istotny wpływ na rozwój miast (szerzej - por. Gawlas 2006, s. 83 i nn.). Monopolizacja wyższego sądownictwa miała swój finansowy aspekt. Narzędziem eksploatacji poddanych była odgórnie forsowana monetaryzacja wymiany i świadczeń. Wprowadzona w XII wieku regularna wymiana monety brakteatowej przetrwała aż do reformy groszowej i zmian w mennictwie w XIV wieku. Kontrolę obiegu pieniężnego zapewniała sieć targów. W ramach kolonizacji niemieckiej powstał model całościowej reorganizacji osadnictwa, ułatwiający komercjalizację, poświadczony źródłowo dla połowy XII wieku. Nawiązywał do niego przywilej chełmiński. Funkcje centrów wymiany i zarządu pełniły villae forenses. Zakładanie targów umożliwiało zbyt produktów rolnych i było sposobem zwiększania dochodów wielkiej własności ziemskiej, stosowanym jeszcze w czasach nowożytnych (Lalik 1975, s. 366-380; 1976; Maroszek 1990; Studia średniowieczne 2006, s. 350-365; Wroniszewski 2001, s. 20 i nn.). Specyfiką rozwoju naszego regionu było stosunkowo szybkie zatarcie różnicy 
między statusem miasta i targu. Wiąże się z tym problem prawa średzkiego i jego ewolucji, dobrze rozpoznany w literaturze przedmiotu. Zwracając w tym miejscu uwagę na dwutorowość procesu urbanizacji i funkcje małych miast koncentruję się dalej na dużych ośrodkach.

Podstawowym sposobem kontroli dochodów z handlu była książęca własność urządzeń handlowych, sięgająca głęboko w czasy poprzedzające kolonizację niemiecką. Początkowo dotyczyła karczm oraz jatek. Status prawny karczmy jako instytucji prawnej i konkretnego miejsca w przestrzeni osadniczej wydawał się zagadnieniem stosunkowo dobrze zbadanym w literaturze (Cieśla 1958, s. 159-222; Rabęcka-Brykczyńska 1964, s. 373-375; 1974, s. 10 i nn.). Po ponownym przyjrzeniu się problemowi można sformułować opinię, że jest on mocno uwikłany w kontekst wyobrażeń o ustroju prawa polskiego oraz funkcjonowania regaliów (Buczek 1964, s. 68-79; 1970, s. 479-484). Poza stwierdzeniem związku karczm z gospodarką pieniężną i targami, a także przeprawami oraz istnieniem dużych skupisk ,tabern” w niektórych dużych ośrodkach (Trawkowski 1958; 1962, s. 207-221; 2005, s. 222-255; ostatnio - Stelmach 2012, s. 77-91), prawie nic konkretnego o nich nie wiemy. W związku z tym ich rolę i charakter zabudowań wyobrażamy sobie w oparciu o opisy późnośredniowieczne czy nowożytne (Cieśla 1958, s. 187 i nn.; Buczek1964, s. 69, przypis 17). Jednak funkcje karczm jako instytucji życia społecznego uległy, w wyniku głębokich przemian towarzyszących urbanizacji, sprecyzowaniu i zapewne także redukcji. Interpretacja wzmianek źródłowych, w tym samego terminu taberna czy ius tabernanarum, jest bardziej skomplikowana niż się z pozoru wydaje i wymaga dla XII i XIII wieku ponownego zbadania. Dotyczy to także jatek rzeźniczych, które należą do starszej warstwy urządzeń handlowych, ale pewniejsze informacje pochodzą dopiero z początku XIII wieku . Bardziej jednoznacznie z czasami lokacji łączą się kramy, domy kupców i sukiennice; tu występują duże regionalne różnice. Istniały różne warianty kontroli obcych kupców, w Pradze pełnił je Tyński Dwór (Kejř 1998, s. 217 i nn.; Goliński 2000a, s. 127-137; 2000b, s. 139-145). Ze ścisłą reglamentacją urządzeń handlowych na Śląsku Henryka Brodatego wiążę ich koncentrację na obszarze bloków śródrynkowych, jako podstawy regularnego układu przestrzennego (Gawlas 2005, s. 153 i nn., por. Czerner 2002). Występują one w takiej funkcji wszędzie tam, gdzie szerzył się model śląski.

3. Społeczne uwarunkowania lokacji, z punktu widzenia genezy stanu mieszczańskiego w Polsce, wnikliwie rozważył niedawno Mateusz Goliński (Goliński 2012, s. 7-76). Starał się w związku z tym odpowiedzieć na cały szereg

\footnotetext{
${ }^{7}$ Autor zdecydowanie podkreśla tożsamość wczesnośredniowiecznej instytucji karczmy i jej funkcji w czasach późniejszych.

${ }^{8}$ W tej sprawie obserwacje oparte na wnikliwej znajomości realiów przedstawił Mateusz Goliński (1991, s. 7 i nn.). Odróżnienie starszej opłaty ubojowej od późniejszej jatki obsługiwanej przez wyspecjalizowanych rzemieślników (Rabęcka-Brykczyńska 1974, s. 12 i nn.) ma jednak słabe uzasadnienie źródłowe.
} 
zasadniczych pytań. Jak przekształciło się miasto - siedziba władzy, instytucji kościelnych i możnych w miasto handlowo-produkcyjne na prawie niemieckim? W jakiej mierze można mówić o ciągłości osadniczej i ludnościowej? Co się stało z dworami możnowładczymi i rycerstwem, od kiedy realnie funkcjonowała zasada „powietrze miejskie czyni wolnym”? W jakiej mierze odpowiadały rzeczywistości wzmianki dokumentów o masowym napływie obcych osadników i ich separowaniu od ludności miejscowej? Jaki był rzeczywisty jej udział, a zwłaszcza słabo poświadczonych w źródłach niższych warstw społecznych, których migracje z bliskiego zaplecza, przynajmniej na przedmieścia, zapewniały niezbędną obsługę kształtujących się elit komunalnych? Dla funkcjonowania miast zasadniczą rolę pełnił stały przepływ ludności ze wsi do miast i z miast mniejszych do większych. Przybysze musieli się asymilować do reguł i stylu życia określonych przez tych, którzy przybyli wcześniej. Jak więc przebiegał proces przekształcania gminy kupieckiej w miasto o przewadze liczebnej ludności rzemieślniczej? W pierwszych pokoleniach mieszczan kontakty ze słowiańskim zapleczem zapewniały małżeństwa mieszane, ponieważ przybysze brali za żony kobiety o słowiańskich imionach. Pojawiająca się w miastach kultura materialna była jednak wyraźnie nowym zjawiskiem. Mateusz Goliński łączy informacje zawarte w źródłach pisanych $\mathrm{z}$ interpretacją wskazówek dostarczanych przez archeologów, w tym zwłaszcza dotyczących garncarstwa, blisko związanego z kulturowo-etnicznymi upodobaniami użytkowników tych wyrobów. Niezależnie od limitowanych przez materiał źródłowy odpowiedzi już samo postawienie problemów wskazuje na złożoność i zróżnicowanie zjawisk społecznych towarzyszących powstawaniu mieszczańskich gmin.

$\mathrm{Z}$ napływem przybyszy wiąże się sprawa statusu gości - hospites - w słowiańskim otoczeniu. W tej sprawie należy przywołać ustalenia Christiana Lübke, który pokazał bardzo starą genezę książęcej opieki nad kupcami (Lübke 2001, s. 123 i nn., s. 177 i nn.). Tak jak inni cudzoziemcy, tracili oni w obcym i wrogim otoczeniu opiekę prawa. Zastępował ją patronat władcy, który wywodził się z uniwersalnych zasad gościnności wobec przyjętych pod dach obcych. Książę gwarantował kupcom ich wolność i prawa, ale kosztem daleko idącej zależności. Za klasyczne świadectwo statusu miejskich przybyszy uchodzi przywilej Sobiesława II (1176-1178) dla Niemców praskich (Urkunden und erzählende 1970, s. 352-357)9 . Oznajmiał on, że in graciam et defensionem suscipio Theutonicos qui manent in suburbio Pragensi i oddzielił ich prawnie od Czechów. Przyznał im prawo wyboru własnego plebana i sędziego. Inni przybysze i goście (advenae vel hospites) mieli podlegać ich prawom i zwyczajom, które zostały opisane. Sądownictwo krwawe (homicidio), czyli wyższe, władca rezerwował jednak dla siebie, do niego należało także rozstrzyganie spraw między Niemcami a ludnością czeską. Sądy i przysięgi miały się odbywać tylko przed kościołem św. Piotra, na rozkaz księcia. Osada

\footnotetext{
${ }^{9}$ W sprawie przekazu dokumentu - por. Kejř 1969; 2006, s. 93-128.
} 
przybyszy posiadała jakąś własną przestrzeń i kilka ulic, skoro zabójstwo osoby, która wędrowała w nocy bez pochodni per vicos Theutonicorum nie powodowało oskarżenia ich mieszkańców (Kejř 1998, s. 74 i nn.). Wykrycie nielegalnej propinacji (taberna occulta) w domu Niemca powodowało uwięzienie jego właściciela w obecności iudice Theutonicorum vel eius nuncio.

Świadectwem istnienia pierwszych gmin niemieckich gości we Wrocławiu i Krakowie w latach 20.-30. XIII wieku są wzmianki o sołtysach. Ostatnio Jerzy Rajman opublikował ulepszoną wersję analizy kształtu tej pierwszej krakowskiej civitas (Rajman 2012, s. 47-86). Wbrew zgłaszanym w literaturze wątpliwościom badacz ten słusznie uznaje ją za osadę miejską, która miała być organizowana od około 1220 roku przez Piotra, jeszcze jako książęcego włodarza. Wzmianki źródłowe wskazują, że zamieszkiwali ją głównie kupcy. Za prawdopodobny uznaje jej wydłużony kształt przestrzenny, z centrum położonym od placu rozciągającego się przed parafialnym kościołem Trójcy Świętej ${ }^{10}$, dalej na północ do powstającego kościoła Mariackiego. Pierwszy został oddany w 1222 roku dominikanom, a do drugiego przeniesiono prawa parafialne. Takie położenie potwierdza, później poświadczona, lokalizacja jatek na Małym Rynku, na tyłach kościoła Mariackiego (Rajman 2004, s. 175 i nn., s. 328 i nn.). Tu także mogły przed wielką lokacją znajdować się krakowskie karczmy (taberny), bardzo słabo jednak poświadczone.

Możemy przypuszczać, że do standardów ówczesnego modelu miasta na prawie niemieckim odwoływał się przywilej chełmiński z 1233 roku, ale informacje w nim zawarte nie pozwalają na bliższą charakterystykę kształtu planowanych miast (Zielińska-Melkowska 1986; Luciński 1990, s. 81-139). Zakon gwarantował w nim wolność corocznego wyboru sędziego przez mieszczan, jednak za swoją zgodą. Rezerwował dla siebie kontrolę i $2 / 3$ kar sądowych z sądownictwa krwawego (de maioribus culpis, ut sunt homicidia, sanguis effusio et similia). Sędzia pobierał pozostałą 1/3 oraz całość opłat ze spraw drobniejszych do 12 denarów (minorum excessum, que cottidiana dicitur). O połowę została obniżona wysokość kar przewidzianych prawem magdeburskim i miała być płacona w monecie chełmińskiej. Mieszczanie uzyskali wolność od nadzwyczajnych podatków ( $a b$ omnibus collectis iniustis), utrzymywania gości (hospitacionibus coactivis), a także innych nienależnych świadczeń (aliisque exaccionibus indebitis). Zakon uposażył kościoły, ale zachował prawo patronatu. Udzielił miastom prawa do wolnego przewozu przez Wisłę, jednak z zastrzeżeniem bezpłatnego przewozu braci, ich ludzi i wszystkich posłów. Gwarantował też, że nie będzie nabywać domów z naruszeniem praw i zwyczajów mieszczan. W ziemi chełmińskiej wprowadzona została moneta o stałej wartości. Wymiana brakteatów miała następować co 10 lat. a więc po ich fizycznym zużyciu bez nadmiernych opłat (14 starych na 12 nowych monet) (Paszkiewicz 2009, s. 39 i nn.). W przywileju obszerniej opisane zostało uposażenie ziemskie, związane z nim uprawnienia i obowiązki militarne. Obrót

${ }^{10}$ Na placu nie były dotychczas prowadzone badania archeologiczne (Rojkowska 2014, s. 105 i nn.). 
ziemią odbywał się tylko za pośrednictwem Zakonu. Zatrzymał on też szereg regaliów: jeziora, bobry, źródła solne, kopalnie złota i srebra ${ }^{11}$, a także kontrolę nad łowami. Jak wiadomo Toruń powstał na obecnym miejscu w 1236 roku i obejmował początkowo tylko część późniejszego Starego Miasta, z kościołem św. Jana Chrzciciela i położonym obok blokiem urządzeń targowych (zwanych później Werder), z jatkami mięsnymi na czele (Jasiński 1990, s. 100 i nn.; Mikulski 1996, s. 7-24; 1999, s. 23 i nn.).

4. W 1237 roku, a więc niemal równocześnie i zapewne w nawiązaniu do powstawania w nowym miejscu Torunia, wystawiony został akt lokacji Płocka (fundacio et locatio civitatis) przez Piotra, miejscowego biskupa (1232-1239) oraz kapitułę katedralną (Zbiór dokumentów 1975, nr 9, s. 14-17). Ich partnerem był książę Konrad Mazowiecki, a Bolesław, któremu ojciec wydzielił Mazowsze w 1233 roku (Teterycz-Puzio 2012, s. 216 i nn.) oraz młodszy Siemowit wyrazili swoją zgodę. Biskup obszernie opisał przymusową sytuację, w której się znalazł z konieczności odwzajemnienia księciu immunitatibus et libertatibus i licznych dobrodziejstw. Osoba wystawcy i stosunkowo wczesna data spisania, w czasie kiedy powstawał dopiero schemat formularza tego typu aktu (Kuraś 1971, s. 113 i nn.), wyjaśniają niektóre terminologiczne niejasności tekstu. Zachowany $\mathrm{w}$ oryginale dokument ${ }^{12}$ zawiera wszechstronny opis programu miasta na prawie niemieckim z lat 30 . tego stulecia ${ }^{13}$, który można porównywać ze wspomnianym Toruniem; jest on powszechnie znany, ale niedostatecznie dokładnie interpretowany. Uwaga badaczy skupiła się na lokalizacji wymienionych w nim określeń topograficznych. Przemiany Płocka są złożonym i skomplikowanym problemem. Obecnie zrozumienie tekstu ułatwia wnikliwe rozpoznanie kontekstu przestrzennego w badaniach archeologicznych i zasadnicza weryfikacja interpretacji reliktów najstarszej architektury murowanej z badań Włodzimierza Szafrańskiego (Wczesnośredniowieczny Płock 2002; Płock 2011). Nadal podstawowym problemem jest jednak powiązanie wzmianek w źródłach pisanych z materiałem archeologicznym, który zresztą od strony przestrzennej wykazuje istotne luki. Dotyczą one właśnie obszaru między ulicą Tadeusza Kościuszki a skarpą wiślaną, który zapewne przeznaczony został na założenie nowego miasta. Książę pro locacione nove civitatis [...] aream contulit inter ecclesiam Wyslaui et ecclesiam beati Dominici (Gołembnik 2011, s. 244 i nn.). Podstawowym problemem jest

${ }_{11}$ Właściciel ziemi, na której znalezionoby złoto miał takie uprawnienia quod in terra ducis Slesie, w przypadku srebra obowiązywało prawo Freibergu (Zielińska-Melkowska 1986, s. 40-42).

12 Został on w nieznanym czasie unieważniony przez obcięcie dolnej zakładki wraz z pieczęciami, do zachowanego pergaminu przywieszono pieczęć biskupa Jakuba z Korzkwi (1396-1425) (Trawkowski 1962, s. 206 i nn. - autor wiąże unieważnienie z wykupem tabern kapitulnych w 1299 roku).

13 Problem dostrzegła Anna Rutkowska-Płachcińska (1962, s. 143-150); autorka była jednak zależna od ówczesnego sposobu patrzenia na ustrojowe uwarunkowania początków urbanizacji. 
lokalizacja tego kościoła Dobiechny Wojsławowej ${ }^{14}$. Za wykluczone uważam próby identyfikowania go z kolegiatą św. Michała. Według dokumentu wojewody Żyry z 1185 roku kolegiata Najświętszej Marii Panny (czyli kościół Wojsławowej) miała znajdować się in suburbio Plocensi (Zbiór dokumentów 1975, nr 3, s. 6). Dość przekonujące wydają się sugestie, które szukają dla niej miejsca koło cmentarza, u zbiegu ulic Tumskiej i Tadeusza Kościuszki (Gołembnik 2011, s. 263, 271-275; Polak 2008, s. 223-228), problem nie jest jednak rozstrzygnięty. Uzasadnione jest też wiązanie losów kościoła Wojsławowej z fundacją (już w końcu XII wielu lub w latach 1206-1215) klasztoru Norbertanek. Losy pierwszego żeńskiego konwentu w powstającym mieście są istotnym aspektem jego rozwoju. Siostry zostały usunięte z Płocka w nieznanych okolicznościach, które są przedmiotem rozmaitych hipotez ${ }^{15}$. Osiadły w Promnej nad Pilicą, skąd w 1239 roku wróciły do Płocka (Zbiór ogólny 1919, nr 389, s. 450), zapewne jednak nie na stare miejsce. Ich średniowieczny kościół, ze względu na narastającą katastrofę budowlaną, został rozebrany i na nowo - w latach 1622-1628 - zbudowany w większej odległości od skarpy. Po kasacie w 1819 roku zabudowania uległy z czasem ponownemu zniszczeniu (Nowowiejski 1930, s. 591 i nn.; Kunkel 2006, s. 292-293) ${ }^{16}$.

Dokument z 1237 roku długo uchodził za lokację na prawie polskim i z tego zapewne powodu wypadł z właściwego pola analiz (Buczek 1964, s. 92 i nn., s. 107 i nn.; 1967, s. 1013-1226). Badaczy wprowadzało w błąd przyrównanie uprawnień gości do statusu mazowieckich rycerzy. Sprawę wyjaśnił Marian Dygo, który pokazał ekwiwalentność wysokości główszczyzny za zabicie rycerza-nobila i gościa kupca-rycerza w ówczesnych przepisach prawa (Dygo 1993, s. 3-17). Istnienie mieszczan-rycerzy było w tym czasie zjawiskiem spotykanym w dużych ośrodkach w Rzeszy i Europie Środkowej, a przywilej chełmiński przewidywał dla mieszczan militarne obowiązki (Dygo 1993, s. 14-15; Gawlas 2000, s. 47). Skomplikowane relacje między księciem i biskupem w Płocku oraz długi proces eliminowania uprawnień tego ostatniego pokazała Stella Maria Szacherska (1992, s. 175-188). Można wprawdzie mieć pewne wątpliwości, czy wszystkie elementy jej konstrukcji są nadal aktualne. Dotyczy to powiązania genezy miasta biskupiego z działalnością Aleksandra z Malonne, a zwłaszcza hipotezy o sprowadzeniu przez niego tkaczy walońskich, wspartej wątpliwą analogią wrocławską (Słoń 2006, s. 211-223; 2010, s. 145 i nn.). Dowody wskazujące na wczesny i intensywniejszy rozwój tkactwa w Płocku są późniejsze i dość wątłe (Szacherska 1978, s. 145 i nn.; 1992, s. 181-182). Niezależnie od tego analiza tej badaczki, oparta na bardzo

${ }^{14}$ Karol Buczek uważał dokładną lokalizację za niemożliwą, dopuszczał jednak umiejscowienie miasta na południowy wschód od grodu, gdzie znajdowały się klasztory norbertanek i dominikanów (Buczek 1967, s. 1020-2021).

15 Z obszernej dyskusji - por. Deptuła 1975, s. 80-81; ostatnio Bilska-Ciećwierz, 2007, s. 94-95, 126; Szymaniak 2007, s. 221-236; Kłoczowski 2010, s. 65-66, 168-169, 190-193; Stawski 2010, s. 469-480.

16 Sprawa ta wymaga dalszego wyjaśnienia. 
dobrej znajomości dokumentacji i realiów, ma szersze znaczenie - ponieważ dotyczy słabo dostrzeganego w badaniach, a stosunkowo dobrze poświadczonego w Płocku zjawiska miast biskupich i zakresu własności Kościoła. Jego uprawnienia książęta piastowscy starali się eliminować na progu epoki lokacji. Problem nie jest dostatecznie uwzględniany w badaniach.

$\mathrm{Z}$ dokumentu lokacji Płocka wynika, że w czasie jego wystawienia istniały już dwa miasta: biskupie, określone jako civitas vetera oraz książęce. W tym drugim znajdowała się osada żydowska, jakieś podwale (pomerium), prowadzące do via communis, która znajdowała się przy kościele Dominikanów (domus Predicatorum), sprowadzonych do Płocka w latach 1226-1227 (Wołosz 1998, s. 89-120; Dekański 1999, s. 107 i nn.; Kłoczowski 2008, s. 46-62; 2010, s. 89-97). Ich lokalizacja wskazuje na istnienie już wówczas miejskiej osady książęcej, wzmiankowanej w 1228 roku jako civitas Ploceke (Zbiór dokumentów 1975, nr 8, s. 13; pełen tekst - por. Zbiór ogólny 1919, nr 266, s. 289). Wskazują na to analogie innych ośrodków: Krakowa, Wrocławia, Poznania (nieco późniejszego) (Słoń 2006b, s. 227-245) oraz Gdańska (Dekański 1999, s. 92 i nn.; Spież 2003, s. 176-18477; Możejko, Kaczor, Śliwiński 2006, s. 137 i nn.). Można sformułować sugestię, że w Płocku centrum tej osady określone zostało jako via communis. Być może był to więc wydłużony plac lub ulica targowa (Gawlas 1999, s. 3-25; Polak 2008, s. 229). Z braku możliwości jednoznacznej i dokładnej lokalizacji kościoła Dobiechny kluczowe znaczenie ma sprawa położenia studni oraz studni żydowskiej (puteum Wyslaue ecclesie et alium puteum Iudeorum). Płock ulokowano na wysokiej skarpie wiślanej i ze względów geologicznych istniały trudności z zaopatrzeniem go w wodę (Wysokiński, Gołembnik 2011, s. 39-52). Zapewne dlatego początkowo słabo rozwijało się osadnictwo na północny zachód od kolegiaty św. Michała (Gołembnik 2011, s. 241 i nn.). W późnym średniowieczu i kolejnych latach wodę noszono z Wisły (Sowina 2009, s. 63 i nn., s. 156 i nn.). Problem starano się rozwiązać w XVI wieku, projektując budowę wodociągu czerpiącego wodę z Brzeźnicy (Sowina 2009, s. 269). Z tego względu w 1237 roku studnie były tak znaczącym elementem topograficznym. Za najbardziej prawdopodobne ich położenie należy uznać obszar źródliskowy cieku wodnego u początku ulicy Mostowej (Wysokiński, Gołembnik 2011, s. 471; Trzecieski 2011, s. 63 i nn.). Ze względów komunikacyjnych przy jej wylocie (lub pod grodem) położony był port, wzmiankowany w 1228 roku jako miejsce wystawienia dokumentów dla zakonu dobrzyńców: in portu Plocensi iuxta ecclesiam Beati Benedicti przez biskupa Guntera (1227-1232) oraz in ripa fluminis Wizla contra civitatem Ploceke przez Konrada Mazowieckiego (Zbiór dokumentów 1975, nr 7, s. 12, nr 8, 13; pełen tekst - por. Zbiór ogólny 1919, nr 265, s. 286, nr 266, s. 288-289). Port słusznie

${ }^{17}$ Por. inne artykuły w tomie, zwłaszcza blok pt. „Z badań na terenie klasztoru św. Mikołaja” (s. 399 i nn.). 
ostatnio lokalizowany jest nie po drugiej stronie Wisły, ale pod skarpą (Sowina 2009, s. 71 i nn.; Gołembnik 2011, s. 266; 2015, s. 154-156).

Najnowsze analizy położenia nowego miasta można wesprzeć dodatkowymi argumentami (Polak 2001, s. 24-39; 2008; Gołembnik 2011, s. 267 i nn.). Nie ma wątpliwości gdzie leżało miasto biskupie (czyli stare vetera civitas), które należy utożsamiać z stosunkowo dobrze zbadanym archeologicznie obszarem podgrodzia. Wskazuje też na to dokument z 1247 roku (Zbiór dokumentów 1975, nr 12, s. 18-19), w którym Bolesław, książę mazowiecki, ze względu na spalenie civitatis [...] cum castro et ecclesia, mimo sprzeciwu biskupa Piotra II (1245-1254) obawiającego się utraty własności (perpetua alienacio arearum), swoich mieszczan (cives nostros) zamierzał osiedlić in areis ecclesie et ipsorum canonicorum, które znajdowały się infra suburbium. Mieli tu zbudować swoje domy, nie naruszając praw Kościoła i tak jak kanonicy wypełniać operas debitas et custodiam. Po ustaniu niebezpieczeństwa pruskiego, gdy cives nostri possint extra municiones et suburbium habitare, mieli pod groźbą ekskomuniki całkowicie opuścić własność kościelną i wrócić ad loca propria. W 1237 roku własność Kościoła obejmowała oprócz siedzib kanoników także 12 tabern, które miały pozostać w jego posiadaniu. Sytuacja opisana w dokumencie lokacyjnym była właściwie wymuszoną i nieudaną próbą przejęcia miasta biskupiego w celu scalenia całego obszaru miasta pod władzą księcia i sołtysa - sculteto illius civitatis. Płoccy goście (hospites) uzyskali wówczas w dziedziczne posiadanie obszar osady książęcej cum civitate veteri, $\mathrm{z}$ zachowaniem dochodów Kościoła $\mathrm{z}$ tabern, które należały do uposażenia prebend kanonickich. Granice miasta książęcego zostały opisane z perspektywy katedry i Wzgórza Tumskiego. Wyznaczał je cmentarz (sepulcra) przy drodze prowadzącej do Czerwińska. Sformułowanie sugeruje, że nie była to droga lokalna. Musiała ona dość zdecydowanie odsuwać się na wschód od dalszego przebiegu krawędzi skarpy wiślanej. Miasto obejmowało teraz również całe podwale (totum pomerium) - od wspomnianych studni do placu przy klasztorze Dominikanów.

5. Książę Konrad zakładając nowe miasto (nova civitas) dość dokładnie określił jego wolności (forma libertatis). Gwarantował swobodę handlu na „nowym targu” (novum forum) wszystkim go odwiedzającym - rycerzom, duchownym, wolnym i przypisańcom. Sądownictwo nad mieszkańcami miasta, zarówno Niemcami, jak i Polakami (sive Thewtonicos sive Polonos) miał sprawować sołtys. Wyższe sądownictwo w sprawach krwawych (causa tam aradua, que ad evidenciam ducis deferatur, scilicet pro pugna in gladio, pro percussione in via vel in domo) należało do księcia. Pobierał on także $2 / 3$ kar ze spraw zagrożonych wyższą opłatą (causa magna), resztę zachowywał sołtys, któremu przypadała również całość dochodów ze zwykłych sporów między gośćmi (inter duos hospites de causa simplici). Wysokość ich główszczyzny była równa rycerskiej. Mieszkańcy miasta zwolnieni zostali z przewodu (conductus), ale z wyłączeniem transportu sukna zakupionego w mieście dla księcia oraz konwojowania więźniów - nie dalej niż 
do trzech niezidentyfikowanych miejscowości. Wyjątki nie dotyczyły obszaru po drugiej stronie Wisły, który był całkowicie wolny od przewodu. Zniesiona została dotychczas płacona danina zwana krową podworową (vacca de potuoroue) ${ }^{18}$. Przypływające łodzie nie będą zabierane do użytku księcia i nie będzie stosowana przemoc przed rozładowaniem soli. Władca mógł korzystać jedynie z korabi (naves que vocantur corabe) ${ }^{19}$. Tratwy (navis pleniusca - pletnica?) miały być wolne od użycia przez księcia. Rezygnował on z przymusowej wymiany pieniądza (moneta civibus per vim non proicitur). Mieszczanie (cives) na obszarze ziemi nie płacili ceł, a na wodach zarówno księcia Konrada, jak i Bolesława, znajdowali się pod opieką równą rycerskiej.

Mieszkańcy Płocka nie byli zobowiązani do żadnych opłat oprócz czynszu z tabern. Wszyscy goście (hospites) mieli się cieszyć pięcioma latami wolności ważenia piwa-tabernas braxandi. Po ich upływie księciu należało się 15 grzywien z miasta lub po grzywnie od każdej taberny. Wysokość dochodu miała nie ulegać w przyszłości zmianom. Łącznie z 12 tabernami w rękach Kościoła w Płocku projektowano przynajmniej 27 tabern. Rozumieć je należy jako działki z przywilejem propinacyjnym (Rutkowska-Płachcińska 1978, s. 186 i nn., 191) Ich funkcjonowanie wymagało dostępu do dobrej wody, a przynajmniej jej dostatecznej obfitości (Karst 2002, s. 9-43); jest to dodatkowa wskazówka co do lokalizacji starego i nowego miasta. Wyeksponowanie czynszu z tabern było związane $\mathrm{z}$ ich rolą $\mathrm{w}$ obiegu pieniężnym i można je traktować jako formę jego kontroli. Trudno dociekać, dlaczego nie wymieniono innych urządzeń, na przykład jatek. Planowanie liczby około 30 tabern i stosunkowo niska wysokość pobieranego z nich czynszu może być punktem wyjścia do oceny skali przestrzennej całej aglomeracji. Jako analogia narzuca się „miasto piwne” - Świdnica, założone niemal w tym samym czasie, około 1240 roku; jego program planowany był początkowo na 150 działek (Chorowska, Karst, Lasota 1998, s. 157-177; Goliński 2003, s. 73; Chorowska, Lasota 2013, s. 23 i nn.). Świdnica była miastem o wyjątkowym sukcesie wspomnianej specjalizacji (Goliński 2000c, s. 29 i nn.; Chorowska, Lasota 2013, s. 45 i nn.). Jej rozwój umożliwiło odpowiednie zaopatrzenie w dobrą wodę i organizacja odprowadzania nieczystości (Goliński 2003, s. 66 i nn.; Cembrzyński 2011). W Toruniu staromiejski cech karczmarzy w początku XV wieku liczył 57 mistrzów (Mikulski 1999, s. 81 i nn.). Przed powiększeniem obszaru miasta po 1252 roku o rynek i nowe bloki zabudowy skala tego rzemiosła nie odbiegała więc zapewne od tej odnotowanej dla Płocka. Należy też odnotować argumentację sugerującą porównywalną liczbę tabern we Wrocławiu w 1. ćwierci XIII stulecia (Goliński 1991, s. 7-19, s. 85 i nn., s. 165).

18 Trudno sprecyzować charakter tej daniny, możliwe, że był to okolicznościowy stan. Powątpiewam czy nazwa musiała odpowiadać formie jej płacenia, w tym czasie uległa ona zapewne już reluicji. Stanowiska prezentowane w tej sprawie w literaturze - por. Matuszewski 1936, s. 425-426; Buczek 1972, s. 213-243; 1975, s. 206; 2006, s. 171-210; Modzelewski 1987, s. 79-84.

19 Zapewne były to nadal jednopienne dłubanki (Ossowski 1999; 2010). 
Trzeba jednak pamiętać, że podobna do Świdnicy liczba działek z przywilejami piwnymi występowała w Poznaniu w 1253 roku i nieco wcześniej datowanym Dzierżoniowie - Reichenbachu (Rogalanka 1977, s. 323-376; Gąsiorowski 1988, s. 221; Chorowska 2005, s. 207-224). We Wrocławiu wielkie rozmiary produkcji piwa doprowadziły jeszcze w XIII wieku do wyodrębnienia się słodowników jako osobnego zawodu; ich siedziby zlokalizowane były w kwartale położonym poza murami miasta lokacji z 1241 roku (Goliński 1997, s. 140 i nn.; Okólska 2002, s. 47-57). Na początku XV wieku miasto liczyło niemal 400 karczmarzy i posiadaczy działek z przywilejem taberny. W tym czasie było już zaawansowane zjawisko rozłączania przywileju taberny od innych zawodów rzemieślniczych (Goliński 1997, s. 498 i nn., s. 501, plan nr 4). W Krakowie, jak się zdaje, liczba piwowarów była zdecydowanie mniejsza, ale opłaty od wyszynku stanowiły jedną z ważniejszych pozycji w miejskich dochodach (Kutrzeba 1898, s. 37-5220). Miastotwórcza rola produkcji piwa we wczesnym okresie lokacji miejskich rysuje się jako ważny problem badawczy ${ }^{21}$. Rozwijające się miasta od 2. połowy XIII wieku starały się ograniczyć konkurencję podmiejską przy pomocy prawa mili, zakazującego propinacji i handlu w ich bezpośrednim zapleczu. Pierwszą wzmiankę zawiera dokument lokacji Brzegu z 1250 roku: infra unius miliaris ductum nullam esse volumus tabernam (Schlesisches Urkundenbuch 1977, nr 409, s. 257; por. też Kühler 1964). Wcześniej zakaz ten pojawił się w przywileju Przemysła Otokara I dla Opawy, datowanym na 1224 rok $^{22}$. W Czechach najstarszy przekaz pochodzi z 1265 roku (Žemlička 2014, s. 258 i nn.).

W Płocku w 1299 roku książę Bolesław II, zamierzając condicionem et statum civitatis nostre Plocensis [...] in melius reformari, załagodził spór z biskupem Janem II (1297-1310) i nałożył na wójta, ławników i gminę (advocato, scabinis et universitate civitatis) coroczną opłatę 60 grzywien pro tabernis seu iure tabernarum Kościoła in ipsa civitate Plocensis; pośredniczył biskup poznański Andrzej Zaręba (Zbiór dokumentów 1975, nr 18, s. 24-26). Miasto w 1314 roku obok pieczęci sołtysa dysponowało już pieczęcią własną - tocius civitatis sigillum (Zbiór dokumentów 1975, nr 19, s. 26-27). Próba likwidacji uprawnień duchowieństwa związana była z nową lokacją przestrzenną (obszernie - Polak 2011, s. 311 i nn.; por. też Szacherska 1992, s. 184 i nn.). Można dodać, że w Płocku miała ona miejsce mniej więcej w czasie, kiedy na surowym korzeniu, ale w pewnym nawiązaniu do grodu w Jazdowie, wytyczona została Warszawa - miasto o podobnej skali i analogicznym położeniu na wysokiej skarpie nad Wisłą (Gieysztor i in. 1980, s. 17 i nn., s. 24 i nn.; Suchodolska 2006, s. 233 i nn.). W tym przypadku przy

\footnotetext{
${ }^{20}$ Autor przypuszczał, że w późnym średniowieczu było nie mniej niż 25 piwowarów (Kutrzeba 1898, s. 38-39).

${ }^{21}$ Szczególnie jest ona widoczna w miastach śląskich, na przykład w biskupiej Nysie (Wółkiewicz 2014, s. 33 - tam starsza literatura).

${ }^{22}$ Infra unum miliare tabernae nullae prorsus fiant, sed omnes penitus deponantur, exceptis illis, que sunt in dotibus eccelsiarum (Codex diplomaticus 1912, $\mathrm{nr} 265$, s. 256-257).
} 
wyborze miejsca zapewne zostały wykorzystane doświadczenia płockie, między innymi dotyczące kłopotów z zaopatrzeniem w wodę. Przez warszawską skarpę przepływało kilkanaście strumieni: Kamionka, Strumyk Świętojański, Dunaj, Strumień Nowomiejski itd. (Gromski 1977, s. 24 i nn.).

W Płocku spory z Kościołem trwały także w XIV wieku. W dokumencie z 1322 roku (Zbiór dokumentów 1975, nr 20, s. 27-31) książę Wacław (Wańko) ogłosił dokonaną z biskupem Florianem zamianę wsi i gruntów pod Płockiem oraz rezygnację z czynszu 60 grzywien w zamian za castrum Sierpc, z prawem lokacji tam miasta na prawie średzkim i kilku wsi wraz z pełnym immunitetem sądowym (Kaczmarczyk 1936, s. 281-289). Umowa nie została zrealizowana, a Sierpc pozostał własnością książęcą (Żebrowski 2003, s. 83-100; Salina 2011, s. 131). Dostrzegam w niej tendencję (obserwowaną także w innych ośrodkach) do oferowania biskupowi, mozolnie wypychanemu z powstającego w jego siedzibie książęcego miasta komunalnego, możliwości rozwijania miast we własnych dobrach. Została ona zresztą zrealizowana w biskupim Pułtusku (Zwolińska 1969, s. $2-57)^{23}$, zapewne lokowanym w 1339 roku na prawie chełmińskim ${ }^{24}$, po jego zniszczeniu przez Litwinów ${ }^{25}$. Pułtusk był starym centrum dóbr biskupich, zaś na prawym brzegu Narwi, na obszarze zwanym później Starym Miastem, istniała osada handlowa przy kościele Panny Marii (Pela 2000, s. 11-3426). Nie ma jednak podstaw źródłowych do przyjmowania wcześniejszej daty lokacji ${ }^{27}$.

W tekście umowy z 1322 roku znajduje się cały szereg interesujących informacji dotyczących topografii Płocka. Biskup zachowywał własność suburbio inter civitatem et castrum Plocense infra fossata ibidem constituto, prout eadem fossata se in Wyslam extendunt. Miasto biskupie nazwane zostało teraz suburbium, na którym znajdowały się areae canonicorum. Mieszkający na nich ludzie (także

${ }^{23}$ Materiał kartograficzny - por. Bartoszewicz 2010.

${ }^{24}$ Dokument biskupa Klemensa (1333-1357) dla wójta Mikołaja jest wzmiankowany (bez podania daty) w odnowieniu przywileju z 1380 roku dla wójta Jana, po zniszczeniu jego wcześniejszej wersji w czasie pożaru Warszawy, co może sugerować udział w lokacji mieszkańców Warszawy (KDKM 1863, nr 102, s. 95-96; NKDMaz. 2000, nr 234, s. 249-250; por. też Suchodolska 1980, nr 154, s. 98; Gołembiowski 1990, s. 282-285).

${ }^{25}$ Przemiany przestrzenne przedstawił Włodzimierz Pela (1992, s. 347-358). Lokalizacja miasta na obecnym miejscu nastręczała problemy związane z wysokim poziomem lustra wody na opływających go rzekach (Pela 1997, s. 41-54).

${ }^{26} \mathrm{~W}$ cytowanej pracy na stronie 26 o znalezieniu plomb ołowianych typu drohiczyńskiego; w ustnej rozmowie autor poinformował mnie, że było ich około 100 .

27 Przypuszczenia dotyczące przywileju wydanego rzekomo przez Siemowita I w 1257 roku oparte są na nieprecyzyjnej wzmiance Wincentego H. Gawareckiego (1826, s. 19), wykorzystującego wcześniejsze lokalne domysły, których autorzy odwołali się do wydanego w tym roku w Mistrzewicach potwierdzenia przywilejów biskupstwa płockiego z 1231 roku; w dokumencie nie ma wzmianki o Pułtusku ani o prawie niemieckim (KDM 1863, nr 28, s. 21; NKDMaz. 1989, nr 29, s. 37-30; por. też Kazimierski 1975, s. 12-13; Suchodolska 1980, nr 16, s. 20 i nn., s. 104). Należy dodać, że dokument przywileju z 1257 roku został w latach 1264-1279 podfałszowany (Łodyński 1908, s. 301-315; 1919; Kaczmarczyk 1936, s. 281 i nn.; Matuszewski 1936, s. 419 i nn.). 
w innych domach kanoników) mogli swobodnie sprzedawać bydło i produkty ze swoich ogrodów in civitate Plocensi oraz wypasać bydło wraz z mieszczanami. Tracili jednak prawo do uprawiania jakichkolwiek rzemiosł (artificia mechanica). Spośród zawodów wymienieni zostali: karczmarze (tabernatores), piekarze, szewcy, kowale, kuśnierze i sukiennicy (pannicide). Trudno rozstrzygać, czy wszystkie te zawody były rzeczywiście wykonywane na terenie kościelnym. Nawet jeżeli zinterpretujemy zakaz jako zabezpieczenie lokacyjnego miasta przed możliwą konkurencją, uzyskujemy informacje o kilku obecnych w Płocku specjalizacjach rzemieślniczych. Należy do nich dodać świadkujących w 1338 roku: rzeźnika, szewców i tkaczy (textores) (Zbiór dokumentów 1975, nr 25, s. 43).

Ułamkowe przekazy źródłowe, którymi dysponujemy związane są ze wspomnianymi już sporami z Kościołem. Trzeba mieć świadomość, że dotyczą one tylko niektórych problemów i nie pozwalają na pełniejsze zarysowanie uwarunkowań i sposobu realizacji planowanego w 1237 roku miasta. W świetle dokumentu jego podstawą gospodarczą był handel dalekosiężny solą i suknem, funkcjonowanie portu wiślanego i produkcja piwa. Stojący na czele gminy sołtys wzmiankowany był jeszcze w 1260 roku $^{28}$. Później dzieje polityczne wskazują na kilkakrotne zniszczenie miasta (Suchodolska 2006, s. 219 i nn.). Ze względów źródłowych nie można śledzić rozwoju specjalizacji rzemieślniczo-produkcyjnych oraz ewolucji prowadzącej w kierunku ustroju komunalnego. Można jedynie stwierdzić, że początkiem jego powstawania była nowa lokacja przestrzenna w końcu XIII wieku.

Instytucja kościoła kupieckiego (ecclesia mercatorum) jest starsza niż epoka lokacji i dobrze znana w literaturze (Johansen 1965, s. 85-134; Jasiński 2005, s. 163 i nn. ${ }^{29}$ ). W ciągu XII wieku w Rzeszy Niemieckiej miał miejsce proces powstawania gminy miejskiej ${ }^{30}$. Od końca tego stulecia zwrot duszpasterski w nauczaniu Kościół spowodował, że przywiązywano wielkie znaczenie do faktycznej realizacji obowiązku uczestnictwa w świątecznej mszy (Vauchez 2001, s. 611 i nn.; Skierska 2003, s. 43 i nn., s. 87 i nn.). Rozwój specyficznych form życia religijnego stanowił bardzo ważny aspekt wewnętrznego procesu scalania miejskiej przestrzeni. Ich źródłowym przejawem były fundacje: kościoła parafialnego, klasztorów mendykanckich i szpitali. Na znaczenie tego zjawiska zwrócił uwagę ostatnio Marek Słoń (2006b, s. 228 i nn.). W Polsce własny kościół towarzyszył początkom gminy gości w największych ośrodkach: św. Wojciecha we Wrocławiu, św. Trójcy w Krakowie, św. Małgorzaty w Poznaniu, św. Mikołaja w Gdańsku. Wszystkie przekazane zostały pierwszym konwentom dominikańskim, a ich funkcje przejęły nowe kościoły. Inicjatywa fundacji mendykanckich należała

\footnotetext{
${ }^{28}$ Henrico quoque sculteto de Plocsk (Zbiór dokumentów 1975, nr 17, s. 24).

29 Autor analizuje między innymi funkcje kościołów św. Gotharda, położonych na lądowym szlaku Hildesheim - Brandenburg - Poznań - Kruszwica - Włocławek; o roli mendykantów - por. Samsonowicz 2014, s. 185 i nn.

${ }^{30} \mathrm{~W}$ tej sprawie ostatnio - Igel 2013, s. 31-46.
} 
do książąt. Podobnie było z inną miejską instytucją - pierwszymi szpitalami (Słoń 2000, s. 5 i nn.; 2006b, s. 37 i nn.; Escher, Hirschmann 2005, s. 265 i nn. ${ }^{31}$ ). W przypadku Płocku nic nie wiemy o kościele parafialnym dla pierwszej gminy gości. Może była ona jakoś związana z kościołem Wojsławowej, z którego usunięto norbertanki (dlatego znalazły się w Promnej, skąd wkrótce wróciły), jednak brak przesłanek do dalej idących hipotez. Kościół Dominikanów nosi wezwanie św. Dominika i został zapewne ufundowany dla tego konwentu (Szyma 2011, s. 298 i nn.). W mieście lokacji przestrzennej funkcje parafialne pełniła w 1338 roku kolegiata św. Michała ${ }^{32}$. Kościół św. Bartłomieja powstał dopiero w 1356 roku z inicjatywy Kazimierza Wielkiego (Spominki 1996, s. 129). Podczas nowej lokacji Bolesław II wykorzystał starszy kościół należący do jego patronatu. Problem kolegiaty św. Michała otwiera różne interpretacyjne możliwości ${ }^{33}$. Przesłanki wskazujące na jej starszą, jeszcze XII-wieczną genezę i hipotetyczną fundację Bolesława Kędzierzawego zostały ostatnio dość przekonująco zakwestionowane (Deptuła 1975, s. 76-77; Bilska-Ciećwierz 2007, s. 70-71, 81, 123). Jednak materiał porównawczy (Bilska-Ciećwierz 2007, s. 41) nie pozwala tego wykluczyć, zwłaszcza, że w sąsiedztwie odkryto pochówki datowane na XII wiek (Gołembnik 2011, s. 241 i nn.; Trzecieski 2011, s. 72). W każdym razie Konrad Mazowiecki ufundował budowę murowanej kolegiaty zapewne przed 1228 rokiem. Jej architektura i technika budowlana sugeruje nawiązanie do wzorów śląskich (Szyma 2011, s. 279 i nn.). Podjęta inwestycja, jej położenie i status kolegiaty są ważnym, a nie rozwiniętym w niniejszych rozważaniach, przejawem rywalizacji Konrada Mazowieckiego z miejscowym biskupem o kontrolę nad przestrzenią Płocka. Wraz z fundacją klasztoru Dominikanów towarzyszyła ona zabiegom wokół rozwoju miasta książęcego, poprzedzającym lokację z 1237 roku. Można z nimi ewentualnie wiązać także pierwsze przywileje immunitetowe dla Kościoła z lat 1230-1231 (Mitkowski 1960, s. 39-51).

W tym miejscu trzeba także dodać, że całościowa analiza rozwoju uposażenia biskupstwa płockiego, a zwłaszcza uprzywilejowania immunitetowego dóbr, może dodatkowo oświetlić okoliczności powstawania miasta na prawie niemieckim. Jak wiadomo w środowisku katedralnym między 1264 a 1279 rokiem dokonano interpolacji lub fałszerstwa całego szeregu wcześniejszych przywilejów (z lat 1231, 1239, $1240,1241,1252,1257) \mathrm{w}$ intencji poszerzenia zakresu sądownictwa nad wolną ludnością w dobrach kościelnych (Łodyński 1908, s. 301-315; 1919; Kaczmarczyk 1936, s. 281 i nn.; Matuszewski 1936, s. 4189 i nn.). Zabiegi okazały się skuteczne, ponieważ zostały wkrótce zaakceptowane przez książąt. Jednak posunięcie się do takiej metody pośrednio świadczy o trudnościach w uzyskaniu kompromisu

\footnotetext{
31 Książkę udostępnił mi M. Pauk.

${ }^{32}$ Ecclesia sancti Michaeli parochiali (Zbiór dokumentów 1975, nr 25, s. 43; por. też Polak 2011, s. 321 i nn.).

${ }^{33} \mathrm{Z}$ kolegiatą wiązana jest wzmianka o Alardo preposito de ecclesia sancti Michaeli wśród świadków dokumentu Konrada Mazowieckiego z 1218 roku (Zbiór ogólny 1919, nr 200, s. 193).
} 
między władcą a biskupem. W tej sytuacji zastanawia charakter przywileju z 1254 roku, w którym Ziemowit I, za zgodą baronów, miał zaakceptować opieczętowany dokument (nie jest on znany) biskupa Andrzeja (1254-1260), gwarantujący wolność (libertas) dla hospites de quacumque nacione ad incolendas terras dicto episcopatus. Goście zasiedlający villas, fora, burgos, seu eciam civitates mieli cieszyć się pleno iure Theutonico. Zachowany w oryginale oraz widymacie legata Filipa, biskupa Fermo z 1279 roku, dokument uchodzi za autentyczny, a jego sformułowania odpowiadają czasom wystawienia (KDKM 1863, nr 24, s. 18-19; NKDMaz. 1989, nr 19, s. 20-21; Suchodolska 1980, nr 11, s. 18). Jednak wielkie plany kolonizacyjne bardzo źle pasują do rozwoju immunitetu w dobrach biskupstwa i nie ma śladów ich realizacji. Nie wspomniał o nich przywilej immunitetowy z 1257 roku i w zasadzie nie poszerzał zakresu wolności przyznanych w 1231 roku. Dokument z 1254 roku był zapewne tylko kolejnym elementem nieudanych prób jakiegoś majątkowego kompromisu z biskupem.

6. Rozciągnięty na stulecie proces ograniczania własności Kościoła w Płocku, pod powtarzającą się presją książąt w związku z lokacją na prawie niemieckim, jest dobrym punktem wyjścia do postawienia pytania dlaczego na ziemiach polskich prawie nie doszło do wykształcenia się miast biskupich w siedzibach ich diecezji. Sytuacja ta jest zaskakująca z perspektywy Rzeszy Niemieckiej, gdzie w rękach Kościoła znajdowało się bardzo wiele miast ${ }^{34}$. Największe $\mathrm{z}$ nich w czasach pełnego średniowiecza całkowicie się usamodzielniły. Biskupów wypychał z ich siedzib miejski ruch komunalny ${ }^{35}$. Na ziemiach polskich kontrolę nad procesami urbanizacji przejęli książęta i nie dopuścili do szerszego rozwoju miast biskupich. $\mathrm{W}$ poniższych uwagach ograniczam się w tej sprawie do zwięzłego zarysowania problemu na przykładzie kilku kolejnych siedzib diecezji.

We Wrocławiu i Poznaniu doszło do przeniesienia głównego ośrodka na drugi brzeg rzeki z pozostawieniem starego centrum w rękach Kościoła. Był to długi i dość skomplikowany proces, przebiegający w wielu etapach. Najpierw możemy go obserwować we Wrocławiu ${ }^{36}$. W pierwszej fazie głównym przeciwnikiem księcia nie był zresztą biskup, ale rodzina Włostowiców (Manikowska 2000, s. 37-57). Bolesław Wysoki rozpoczął budowę na Ostrowie Tumskim murowanej rezydencji, którą kontynuowali jego następcy (Małachowicz E. 1993; Chorowska 2003, s. 45 i nn., s. 59 i nn.; Buśko 2005, s. 180 i nn.; Żurek 2006, s. 69-84). Henryk III ustąpił biskupowi w 1257 roku działki na obszarze grodu i opisał

${ }^{34}$ Z olbrzymiej literatury - por. Bischofs- und Kathedralstädte 1976; Hirschmann 2011; Escher, Hirschmann, Die urbanen Zentren 2005, s. 412 i nn., s. 422 i nn., s. 424 i nn., 449 i nn., s. 463 i nn., s. 473 i nn., s. 485 i nn. Dziękuję Marcinowi Paukowi za zwrócenie uwagi i udostępnienie tych nowych pozycji. Ostatnio - Hirschmann 2013, s. 67-80 i cały szereg innych artykułów w tomie.

35 W tej sprawie - por. Schulz 1992; por. Wółkiewicz 2010, s. 81, 103-105.

36 Podstawowe znaczenie dla interpretacji wzmianek źródeł pisanych zachowuje Marta Młynarska-Kaletynowa 1986, s. 44 i nn.; 1995, s. 9-26. Nowsze badania uwzględniają: Buśko i in. 2001, s. 67 i nn.; Piekalski 2010, s. 47 i nn.; ostatnio - Piekalski 2014, s. 40 i nn., s. 70 i nn. 
granicę z terenem należącym do książęcego castrum lapideum (Schlesisches Urkundenbuch 1984, nr 247, s. 164). Dalsze zmiany przyniosła fundacja kolegiaty św. Krzyża, a następnie utrata przez zamek po 1310 roku funkcji rezydencjonalnych (Goliński 1997, s. 250 i nn.). W połowie XIV wieku (ostatecznie w 1439 roku) Tum przekształcił się w sacerdotum civitas ${ }^{37}$, którego mieszkańcy popadali w różne spory z komunalnym Wrocławiem (Buśko i in. 2001, s. 158 i nn.).

Na lewym brzegu Odry osadnictwo rozwinęło się w XII wieku przy przeprawie przez rzekę i wokół kościoła św. Wojciecha (Małachowicz M. 2000, s. 189-193; Buśko 2005, s. 177-194). Zapewne Bolesław Wysoki dołączył do niego osadę walońskich tkaczy (Słoń 2007, s. 11-2038; 2010, s. 150 i nn.). Istniała także gmina żydowska. W początku XIII wieku już cały szereg osad składało się na civitas Wraclau (Schlesisches Urkundenbuch 1971, nr 95, s. 68). Henryk Brodaty od początku panowania przystąpił do reorganizacji forum Vratislaviense (Schlesisches Urkundenbuch 1971, nr 115, s. 81). W 1214 roku przy okazji fundacji szpitala św. Ducha pojawił się po raz pierwszy sołtys (scultetus) (Schlesisches Urkundenbuch 1977, nr 142, s. 101; Słoń 2000, s. 80 i nn.). Książę zachował nad Odrą dość znaczny obszar, gdzie postał dwór, a z czasem lewobrzeżny zamek i fundacje klasztorne (Małachowicz E. 1994). W latach 20. XIII wieku rozpoczęło się na nowym terenie, na zachód od kościoła Marii Magdaleny, wytyczanie działek wokół rynku, następnie regularna parcelacja wkroczyła na dalsze tereny (Rynek wrocławski 2001; 2002; Chorowska 2010, s. 67-89). Władca przystąpił do likwidacji konkurencyjnych urządzeń handlowych na Ołbinie (Młynarska-Kaletynowa 1986, s. 110 i nn.). Obserwowany dla tego czasu w źródłach wzrost aktywności majątkowej biskupa Wawrzyńca (Młynarska-Kaletynowa 1986, s. 88 i nn.) wymaga, jak sądzę, dalszej analizy w szerszym kontekście. Przemiany instytucji religijnych w powstającym wielkim mieście wymagały współudziału, a przynajmniej akceptującej reakcji biskupa. Zachował on zresztą prawo patronatu nad kościołem Marii Magdaleny (Goliński 1997, s. 76-77, s. 94-95) ${ }^{39}$. Jednak na jego szerszą partycypację w korzyściach z polityki miejskiej nie było we Wrocławiu miejsca. Biskupi swoją aktywność ekonomiczną i kolonizacyjną już wcześniej przenieśli do dóbr ziemskich o specjalnym statusie (Wünsch 2002, s. 199-264; Wółkiewicz 2008, s. 225-234) i otoczyli opieką własne miasto - dobrze rozwijającą się Nysę (Wółkiewicz 2013, s. 5 i nn.). Dążyli także do poszerzenia zakresu swojej władzy terytorialnej w kasztelanii milickiej (Chorowska 2008, s. 129-142; Paroń 2008, s. 97-128) ${ }^{40}$. Mocna pozycja wrocławskich Piastów wobec Kościoła opóźniła, jak

37 Por. także Słoń 2000, s. 38 i nn.; określenie zaczerpnięte zostało z Descriptio totius Slesie, Bartłomieja Steina.

38 Por. inne artykuły w tej pracy zbiorowej.

39 Drugi kościół parafialny św. Elżbiety został przekazany szpitalowi krzyżowców z czerwoną gwiazdą, co w późnym średniowieczu było powodem licznych konfliktów z dążąca do kontroli nad nim radą (Słoń 2000, s. 131 i nn.).

40 Por. inne artykuły w tej pracy zbiorowej. 
wiadomo, jego emancypację i była przyczyną dramatycznych sporów (Irgang 2003, s. 108 i nn.). Z pewnością ułatwiła władcom ich działania na obszarze Wrocławia. Zamieszanie po najeździe w 1241 roku umożliwiło pewne usamodzielnienie się gminy miejskiej, a lokacja objęła, jak sądzę, centralną część miasta. Henryk III nadał mu w 1261 roku prawo magdeburskie i uregulował cały szereg spornych kwestii, w tym zawłaszczanie przez mieszczan ogrodów i podległość sądową ludzi mieszkających infra fossata prime locacionis (Schlesisches Urkundenbuch 1984, nr

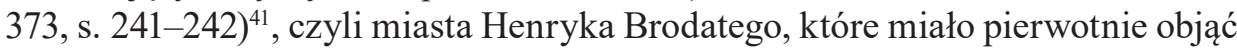
większy obszar. W tym czasie przeprowadzona została regulacja przestrzenna rejonu Nowego Targu i założone, w 1263 roku, Nowe Miasto (Słoń 2010, s. 150 i nn.). Henryk IV Probus nadal kontrolował całość aglomeracji i forsował swoje prawa wobec powstającej biskupiej ziemi nysko-otmuchowskiej (np. Goliński 2005a, s. 49-62; 2005b, s. 41-53²; Piekalski 2005, s. 39-48). Ugoda z Tomaszem II, a przede wszystkim zasadnicze osłabienie władzy jego następców po opiekuńczych rządach Bolka Świdnickiego (Gawlas 2000, s. 90) i następnie przejście księstwa pod władzę Korony Czeskiej, umożliwiły pełne usamodzielnienie polityczne komunalnego Wrocławia. Mieszczanie nie dopuścili do wykorzystania sytuacji przez biskupa i często skłóconą z nim kapitułę. Wspomniane sacerdotum civitas było głównie określeniem topograficznym skupiska kleru i obsługujących go ludzi (Małachowicz E. 1992, s. 92 i nn.; Słoń 2000, s. 38 i nn.).

7. Rozwój przestrzenny Poznania był w jeszcze wyższym stopniu uwarunkowany skomplikowanym układem odnóg rzecznych oraz wysepek Warty i jej lokalnych dopływów ${ }^{44}$. Pierwsza gmina miejska powstała z inicjatywy Władysława Odonica na obszarze Śródki, na wschód od grodu i katedry. Nazwa sugeruje istnienie już wcześniej targu przy kościele św. Małgorzaty (Kaczmarczyk 1953, s. 148 i nn.; Jurek 2005, s. 175, przypis 13; Pawlak 2005, s. 62 i nn.). W 1231 roku zostali w nim osadzeni dominikanie (Spież 2004, s. 9-10). Zapiska rocznikarska informuje o przegranym w 1245 roku sporze jej mieszkańców (określonych jako cives lub może hospites) z biskupem Boguchwałem (1242-1253) i kapitułą o pastwiska nadrzeczne (Rocznik kapituły gnieźnieńskiej 1962, s. 8, 19) ${ }^{45}$. Hipotetyczna rekonstrukcja układu przestrzennego osady jest oparta na bardzo słabych przesłankach, ale jej skala nie mogła być duża (Rogalanka 1988, s. 148-162). Możliwości rozwoju miasta ograniczały warunki terenowe i własność kościelna.

\footnotetext{
${ }^{41}$ W sprawie interpretacji tego dokumentu zgadzam się z opinią Jerzego Rozpędowskiego (1995, s. 42).

${ }^{42} \mathrm{Na}$ artykuł zwróciła mi uwagę Ewa Wółkiewicz.

${ }^{43}$ Por. przypis 37.

${ }^{44}$ Por. tematyczny tom Kroniki Miasta Poznania (nr 1/2014) - Warta; także Kaniewski 2004, s. $102 \mathrm{i} \mathrm{nn.}$

${ }^{45}$ Hipotezę, że w archetypie zapisane zostało [h]oies, a odczytane później jako homines można zastąpić innym domysłem, że w archetypie zapiski został zapisany, w postaci skróconej, wyraz ho[spi]tes.
} 
Na lewym brzegu Warty, przy kościele św. Gotarda, istniała osada obcych kupców, położona na międzynarodowym szlaku handlowym (Jasiński 2005, s. 163-172). Kościół był własnością biskupa. Przemysł I, wraz z bratem Bolesławem Pobożnym i matką Jadwigą, w 1244 roku przekazali go dominikanom, po przejęciu drogą zamiany z biskupem Boguchwałem za kościół św. Wojciecha (Przywileje miasta 1994, nr 2, s. 1-2). Wystawiony z tej okazji dokument jest słusznie uważany za świadectwo przygotowań do nowej lokacji Poznania ${ }^{46}$. Towarzyszyły jej bliżej nieznane starania o przejęcie praw własnościowych Kościoła. Wiążę z nimi - jako formę odszkodowania za stracone dochody - już przywieje immunitetowe Odonica z lat 1232-1237, w tym prawo do bicia monety w biskupiej Krobi (Gawlas 1997a, s. 69 i nn.; ostatnio - Pelczar 2013, s. 362 i nn.). To dość wyjątkowe uprawnienie sugeruje specjalne okoliczności jego nadania (Grodecki 1921; Suchodolski 1987, s. 90 i nn.; ostatnio - Pauk 2010, s. 539-571). Udzielanie przywilejów immunitetowych było narzędziem władzy, a nie zwykłym ustępstwem księcia. Postępowanie Odonica, a następnie działania Przemysła I można interpretować jako (podobną jak w przypadku Wrocławia) tendencję do uprzywilejowania dóbr biskupstwa w zamian za ustępstwa wobec powstającego miasta. W przywileju z 1246 roku książę udzielił zezwolenia na przenoszenie wsi na prawo niemieckie. Pewien wpływ na opóźnianie się lokacji Poznania mogła mieć nieustabilizowana sytuacja wewnętrzna w Wielkopolsce (Nowacki 2003, s. 125 i nn.), ale kilkuletni okres przygotowań był raczej sytuacją normalną, związaną z towarzyszącymi jej trudnościami. Problemy własnościowe naświetla przywilej immunitetowy z 1252 roku, w którym Boguchwał i kapituła wyrazili zgodę na wydzielenie z okręgów parafialnych (de fundo) kościołów św. Marcina i św. Wojciecha obszaru powstającego civitas (Przywileje miasta 1994, nr 2, s. 2-3; Wiesiołowski 2006, s. 7 i nn.). Książę, który był człowiekiem bardzo pobożnym, troszczył się o swój pochówek $\mathrm{w}$ katedrze, przyrzekał bona fide [...] compensacionem facere competentem i gwarantował Kościołowi nadrzeczne łąki po drugiej stronie Warty, połowę dochodów z przeprawy oraz patronat nowego kościoła parafialnego o później poświadczonym wezwaniu Marii Magdaleny. W przygotowanym równocześnie akcie lokacji, wystawionym przez władcę wraz z młodszym Bolesławem wiosną 1253 roku, już oba brzegi Warty miały należeć do miasta. Biskup ponowił zgodę na budowę kościoła parafialnego i odbywanie procesji w dni świąteczne (Przywileje miasta 1994, nr 3, s. 8) ${ }^{47}$. Próba przejęcia kontroli nad farą przez Przemysła II i oddanie jej, ufundowanemu około 1282 roku, klasztorowi Dominikanek okazała się nietrwała (KDW 1982, nr 29, s. 36-37) ${ }^{48}$. Prawa patronatu znajdowały się do

\footnotetext{
${ }^{46}$ Okoliczności wszechstronnie analizuje Tomasz Jurek (2005, s. 173-191), w poniższych uwagach w znacznej mierze korzystam z jego interpretacji.

${ }^{47}$ W sprawie dokumentu - por. Jurek 2005, s. 181.

${ }^{48}$ W 1296 roku książę twierdził, że prawo patronatu: ad nos ex nostris antecessoribus ex tempore cuius non extat memoria pertinet et pertinebat (KDW 1878, nr 743, s. 114). Por. też Gąsiorowski 1977, s. 475-477; Jurek 2003, nr 3, s. 46 i nn.; 2005, s. 185-187.
} 
1555 roku w rękach kapituły i były przyczyną różnych konfliktów z komunalnym już miastem (Dembiński 2003, s. 63-75; 2005, s. 334 i nn.).

Przemysł I odnowił rezydencjonalne funkcje grodu poznańskiego na Ostrowie i w 1247 roku potwierdził in trono ad sanctam Mariam darowiznę Rogalina dla biskupstwa poznańskiego (KDW 1877, nr 264, s. 221; Kara 2006, s. 99-160). W programie lokacji lewobrzeżnego Poznania przewidziano budowę książęcego zamku. Jednak chronologia jego powstawania i program przestrzenny są przedmiotem sporów (np. Linette 1981, s. 28 i nn.; Chorowska 2004, s. 7-226; ostatnio - Ratajczak 2008a, s. 219-242; 2008b, s. 33-54 ${ }^{49}$ ). Wątpię, aby wraz z lokacją doszło do równoczesnej rezygnacji ze starej siedziby, jak jest to często przyjmowane (Kürbis 1988, s. 121 i nn.; Kóčka-Krenz2003, s. 7-26) ${ }^{50}$. Także przebieg lokacji nie wygląda jednoznacznie. Wprawdzie zapiska w „Roczniku kapituły poznańskiej’ informuje, że książę przeniósł w 1253 roku cives suos de civitate, que sita erat in area que vocatur Srothda circa ecclesiam sancte Margarete na drugi brzeg Warty prope de ecclesia sancti Martini, ubi fuerat alia civitas primitus lokata, jednak dokonało się to na naleganie (ad instaciam) pewnego mieszczanina z Gubina. Identyfikuje się go z zasadźcą Tomaszem z Gubina (Rocznik kapituły poznańskiej 1962, s. 32; Szymańska 1953, s. 168 i nn.). Zapiska sugeruje, że inicjatorem przenosin mieszczan nie był książę, ale właśnie zasadźca, który miał własny interes w szybkim powodzeniu lokacji, można też przypuszczać, że pokrywał się on $\mathrm{z}$ dążeniami samych mieszczan ${ }^{51}$. Trudno przesądzać, czy przenosiny mieszczan spowodowały całkowite wyludnienie Śródki, skoro pozostała ona nadal we własności księcia. Przemysł II zrezygnował z niej na rzecz biskupa dopiero w 1288 roku. W dokumencie nazwana została wtedy civitas antiqua. Książę, przekazując wszystkie swoje uprawnienia, sprecyzował omne ius civitatis et eius civibus. Obejmowały one jatki mięsne, piekarskie i szewskie oraz prawo wykonywania wszystkich rodzajów rzemiosł, a także propinacji (tabernas prorsus omnes, qui volunt). Wyłączone zostały jarmarki (forum annuale vel ebdomadarum solempne) oraz możliwość detalicznego handlu suknem (własnym lub sprowadzonym), ale dozwolone były zwykle targi tygodniowe (forum [...] privatum) (Przywileje miasta 1994, nr 8, s. 15-16; Rogalanka 1988, s. 150 i nn. ${ }^{52}$ ). Interpretacja dokumentu nie jest jednoznaczna ${ }^{53}$. Raczej nie jest on odbiciem dotychczasowych funkcji Śródki

\footnotetext{
${ }^{49}$ Autor słusznie dowodzi, że budowę murowanej rezydencji w lewobrzeżnym mieście mógł rozpocząć najwcześniej Przemysł II.

${ }^{50}$ W sprawie grodu - por. Kóčka-Krenz 2014, s. 43-52.

${ }^{51}$ Trzeba jednak pamiętać, że Rocznik jest zachowany w rękopisach tzw. Kroniki Wielkiej i poszczególne sformułowania mogły być przedmiotem późniejszych korekt lub uzupełnień.

${ }^{52}$ Autorka inaczej interpretuje istotne szczegóły nadania. Dziękuję Markowi Janickiemu za konsultacje filologiczne.

${ }^{53}$ Ograniczenie nie dotyczyło targów tygodniowych, a jedynie ewentualnej konkurencji wobec wielotygodniowych jarmarków poznańskich, o których, niestety, posiadamy późniejsze informacje (Gąsiorowski 1988, s. 280-281). Pierwszy z jarmarków zaczynał się w pierwszą niedzielę Wielkiego
} 
i zawiera program nowego miasta biskupiego. W 1293 roku książę przekazał wieś Kobylniki i dołożył do niej locum aput ecclesiam Sancte Margarethe, qui Srodca dicitur (Przywileje miasta 1994, nr 9, s. 16-17) ${ }^{54}$. Ponowne jej nadanie, z prawem ściągania osadników niemieckich i polskich, wspominało jedynie o karczmach i szewcach, jednej jatce mięsnej i jednej chlebowej oraz podkreślało konieczność sprzedaży sukna w Poznaniu. W sumie zakres uprawnień mieszkańców został ograniczony, a biskup dostał w zamian jeszcze podpoznańską wieś, ale zobowiązał się do wieczystego palenia światła na grobie zmarłej księżnej Ryksy. Zapewne wtedy książę przeniósł siedzibę do lewobrzeżnego zamku (Ziółkowska 2004, s. 27-38 $)^{55}$ i próbował dysponować patronatem staromiejskiej fary.

Dokumentacja źródłowa, która powstała w trakcie lokacji Poznania, wykazuje w szczegółach różne niejasności, zapewne po części stanowiące odbicie gry sprzecznych interesów kolejnych władców i ograniczanego przez nich w swoich prawach biskupa oraz kapituły katedralnej. Przekształcanie się Ostrowa Tumskiego w kościelny zespół osadniczy o częściowo miejskim charakterze dopełniło powstanie w XIV wieku miasteczka Chwaliszew, przy przeprawie przez Wartę, pozostającego we własności kapituły (Gąsiorowski 1988, s. 230-232; Słoń 2010, s. 124 i nn.). Można dodać, że w 1. połowie XVI wieku biskup Jan Lubrański otoczył murami obronnymi okolice katedry na Ostrowie (Wawrzyniak 1999, s. $\left.136-139^{56}\right)$.

8. Współcześnie z pierwszą lokacją poznańskiej Śródki, Władysław Odonic założył miasto w Gnieźnie. Niestety, posiadane informacje źródłowe są bardzo skąpe, a stopień ich przedyskutowania w literaturze przedmiotu pozostawia bardzo wiele luk i niejasności (Münch 1946, s. 62-6357; Chłopocka 1965a, s. 122 i nn.; Gniezno 1995; Wędzi 1995, s. 27-43; Chrzest-św. Wojciech 2016). Zachodzące w tym ośrodku przemiany niemal wypadły z pola rozważań nad procesami lokacji miejskich. Generalnie rzecz biorąc Gniezno stanowi bardzo interesujący przykład ośrodka, w którym rozwój przestrzenny miasta na prawie niemieckim, jak się zdaje został zatrzymany na etapie pierwszej lokacji. Nie odnaleziono dotychczas pozostałości wczesnopiastowskiego palatium, które ze względu na rangę Gniezna

Postu i trwał cztery tygodnie, zapewne do niego odnosi się ograniczenie. Następne jarmarki, pięciotygodniowe, zaczynały się na św. Jana i św. Michała. Dokument uważam za pierwszą informację o poznańskich jarmarkach.

${ }^{54}$ Określenie locus mogło oznaczać termin miasto (Stadt) (Gawlas 2000, s. 37).

55 Domysły, że podczas rządów Wacława II mogło dojść do szerzej zakrojonych prac budowlanych uważam za mało prawdopodobne. Rządy Henryka Głogowskiego trwały także zbyt krótko. Niewiadomego pochodzenia informacja w Annales Jana Długosza, dopisana pod 1310 rokiem, o inkastellacji katedry przez wójta Przemka i zniszczeniu domów kanoników, może sugerować próbę przejęcia przez niego dawnej już rezydencji książęcej (Szymańska 1953, s.185 i nn.; Jurek 2006, s. 213 i nn.)

56 Por. inne artykuły w tomie.

${ }^{57}$ W książce streszczenie informacji dotyczących starszej literatury w szczegółach niedostatecznie krytyczne, ale tablice XI i XII zawierają reprodukcje planów z 1797 i 1819 roku. 
powinno powstać na terenie książęcego grodu, zapewne w okolicy kościoła św. Jerzego (Pianowski 1994, s. 56-60). Romańska forma tej świątyni datowana jest na XII-XIII wiek (Sawicki 2001a, s. 163-186; 2016, s. 87 i nn.). Z książęcą rezydencją wiąże się odkrycie pracowni płytek posadzkowych, rewelacyjne ze wyglądu na ich ikonografię (Sawicki 2001b, s. 187-218; Soroka 1990, s. 59-101). Argumenty stratygraficzne sugerują, że została ona zniszczona przed budową murowanego zamku. Ten z kolei jest łączony ze wzmianką rocznikarską pod 1234 rokiem: dux [Władyslaw Odonic] cum filio suo edificavit Gnesnam castrum et destruxit Bnin (Rocznik kapituly gnieźnieńskiej 1962, s. 4; Sawicki 2001c, s. 221-241; 2016, s. 92 i nn.). Stanowi ona słabą podstawę do uznania wymienionego władcy za pierwszego budowniczego murowanej rezydencji. Wskazują jednak na to relikty kamiennych murów, a także względy porównawcze - naśladowanie działalności Henryka Brodatego i może jego legnickiej rezydencji. Przyjęcie takiej chronologii płytek (ewentualnie przed 1192 rokiem) uniemożliwia natomiast interpretację ich ikonografii jako świadectwa rozkwitu kultury rycerskiej na dworze Odonica (Wiesiołowski 2005, s. 194-196 ${ }^{58}$ ). W istotny sposób może też wpłynąć na ogólny obraz jego aktywności w Gnieźnie. Sprawę uważam nadal za otwartą. Można natomiast $\mathrm{z}$ całą pewnością stwierdzić, że murowana rezydencja książęca powstała na Górze Lecha. Już w XIV wieku utraciła swoje znaczenie i została w 1457 roku przekazana przez Kazimierza Jagiellończyka Kościołowi (Sikorski 1995, s. 247-266; Sawicki 2016, s. 93).

Pierwszą informacją o aktywności Władysława Odonica było nadanie templariuszom w 1232 roku hospitale Gniznense wraz z dwoma wsiami (KDW 1877, nr 141, s. 124; Starnawska 1999, s. 56). Szpital przy kościele św. Jana przejęli w 1243 roku bożogrobcy. Już w 1198 roku otrzymali oni położony trochę dalej kościół św. Krzyża, który ofiarował frater Prelaius (KDW 1877, nr 34, s. 44). Szpital znalazł się poza obrębem miasta lokacyjnego (Chłopocka 1965a, s. 128 i nn.; Starnawska 1999, s. 86-87, 230 i nn.; Janiak, Strzyżewski 2001, s. 62 i nn.). Jego powstanie i obecność zakonów rycerskich było raczej związane z funkcjami pielgrzymkowymi Gniezna, ale jest też świadectwem rozwoju miasta. W 1235 roku książę oddał kanonikom gnieźnieńskim wieś Górki wraz z immunitetem pro pomerio quo est iuxta castrum in Gnezdna (KDW 1877, nr 177, s. 154). Zamiana ta jest na ogół łączona z budową zamku, ze względu na przyjęte tłumaczenie słowa pomerium jako sad (Wędzki 1995, s. 27); oznacza ono jednak podwale. Książę pozyskiwał jakiś większy obszar na przedpolu grodu. Dokument powołuje się na zgodę żony i synów. Ta uroczysta forma sugeruje raczej związek z przygotowaniami do lokacji Gniezna na prawie niemieckim. Dokonała się ona przed 1243 rokiem, kiedy wzorem dla lokacji Powidza miał być ius Theutonicale [...] quo cives nostri Gnesnenses utuntur (KDW 1877, nr 240, s. 203-240; Sikora 1969,

${ }^{58}$ Identyfikacja wzorów ikonograficznych niektórych płytek ze scenami z rycerskich romansów nie została poparta obszerniejszą argumentacją. 
s. $61^{59}$ ). W 1239 roku Odonic wystawił przywilej dla Lubiąża in Gneznensi civitate (KDW 1877, nr 220, s. 186). Miasto zostało założone na Wzgórzu Panieńskim, sąsiadującym z grodem i katedrą, ale oddzielonym ciekiem wodnym Srawy. Wczesnej lokacji odpowiada niewielka skala i mało regularny układ przestrzenny miasta, dostosowanego do kształtu morenowego wzgórza (Chłopocka 1965b, s. 142 i nn.; Widawski 1973, s. 127-132) ${ }^{60}$. Nie posiadało ono początkowo własnej parafii; kościół św. Trójcy ufundowano dopiero w 1421 roku (Chłopocka 1965b, s. 146-147; Wędzki 1995, s. 31). Funkcje duszpasterskie pełnił klasztor Franciszkanów, założony zapewne w 1259 roku przez Bolesława Pobożnego. Około 1283 roku powstał przy nim klasztor Klarysek z własnym kościołem (Karczewski 2012, s. 178 i nn.; Szulc 2016, s. 157-173).

Gniezno było główną siedzibą Władysława Odonica po opanowaniu Wielkopolski. Dobre kontakty z arcybiskupem Pełką (1232-1258) miały duże znaczenie polityczne (Pelczar 2013, s. 364 i nn.). Wydany w 1234 roku generalny przywilej immunitetowy wyróżniał status jego dóbr in castelaltura Znegnensi (KDW 1877, nr 174, s. 150-151; Kaczmarczyk 1936, s. 201 i nn.; Matuszewski 1936, s. 315 i nn.). W 1235 roku książę oddał arcybiskupowi dwie wsie zabrane przez poprzednika, a kolejną nadał (wraz z synami) w następnym roku (KDW 1877, nr 179, 199, s. 155-156, 169-170). Z czasem Żnin stał się jednym z głównych centrów majątkowych i pełnił funkcje rezydencjonalne (Warężak 1929, s. 16-19). Arcybiskup Jakub Świnka uzyskał w 1284 roku prawo do bicia w nim monety ${ }^{61}$.

W działaniach książąt wielkopolskich powtarza się podobny motyw uprzywilejowania dóbr arcybiskupich paralelnie do przemian lokacyjnych głównych ośrodków: Gniezna i Poznania. Sprawa wymaga dokładniejszego zbadania w pełniejszym kontekście całego procesu urbanizacji na prawie niemieckim. Siedziby biskupstw odgrywały w nim specjalną rolę. W Gnieźnie nie powstało duże miasto komunalne zdolne do forsowania swoich interesów. Zrezygnowali z tego także władcy i nie doszło do kolejnego powiększenia jego przestrzeni. Pewnych w tej sprawie informacji dostarczają relacje o zniszczeniu Gniezna w 1331 roku przez najazd krzyżacki (Chłopocka 1965b, s. 154 i nn.). Obszar miasta był zbyt mały, skoro wcześnie rozwinęły się osady podmiejskie, część z nich o funkcjach targowych z własnymi kościołami, starszymi od fary św. Trójcy. Chronologia ich rozwoju nie jest jednak jasna (Chłopocka 1965b, s. 157 i nn.; Wędzki 1995, s. 29 i nn.). Tylko dwa przedmieścia należały do miasta - Targowisko z kościołem św. Wawrzyńca i Wójtostwo z kościołem św. Michała, inne - do Kościoła (w tym Grzybowo). W 1347 roku Kazimierz Wielki w ramach zamiany odstąpił

\footnotetext{
${ }^{59}$ Autor koryguje datę na 1245 rok.

${ }^{60}$ Budowę murów raczej należy przesuwać na czasy odbudowy po najeździe krzyżackim w 1331 roku.

${ }^{61}[. .$.$] in Zneyna civitate sua et alias in castellania Lendensi ubi voluerit, monetam habere liceat$ specialem, que per totum nostrum dominium recipi debeat sicut nostra (KDW 1877, nr 542, s. 502; por. też Suchodolski 1987, s. 94-95).
} 
arcybiskupowi podmiejski młyn (Ksanzi mlyn) na Wełnie i jezioro Jelonek (KDW 1878, nr 1257, s. 581). W późnym średniowieczu i czasach nowożytnych miasto było otoczone przez rozrastającą się własność kościelną. Nie sprzyjało to jego rozwojowi, mimo znaczenia wielkich jarmarków gnieźnieńskich (Topolski 1965, s. 260 i nn., s. 292 i nn.).

9. Inny wariant przemian miał miejsce we Włocławku ${ }^{62}$. Należał on do głównych ośrodków wczesnopiastowskich, ale jego dzieje są jeszcze słabiej poświadczone w źródłach pisanych i rozpoznane w badaniach. Dlatego pozostawiają bardzo wiele niejasności i wątpliwości (Wędzki 1980, s. 525-527; Wojda 1993; 1995; Krut-Horonziak 1998, s. 108-111; Danielewski 2016, s. 72 i nn., s. 132 i nn., s. 211 i nn., s. 287-289). Osada targowa powstała zapewne w XII wieku nad Zgłowiączką i przy przeprawie przez Wisłę. Po prawej stronie rzeki, przy kościele św. Gotarda, w Szpetalu Dolnym, rozwinęła się inna osada kupiecko-targowa, która znalazła się we władaniu benedyktynów. Została ona w latach 30. XIII wieku nadana cystersom. Opactwo zniszczone przez Prusów wkrótce upadło, a jego dobra były przedmiotem różnych sporów własnościowych instytucji kościoła (Szacherska 1960; Bruszewska-Głombiowa 2002, s. 122-133) ${ }^{63}$. Skomplikowaną dyskusję nad początkami biskupstwa można w tym miejscu pominąć (Kujawski 1999, s. 39 i nn.; Radzimiński 1999, s. 73 i nn.). Murowaną katedrę miał zbudować dopiero biskup Michał (1222-1252), który prowadził bardzo aktywną politykę powiększania dóbr i dochodów (Bruszewska-Głombiowska2002, s. 40 i nn.). Świątynia znajdowała się zapewne na dawnym podgrodziu, przy przeprawie przez Wisłę. Obszar podgrodzia przeszedł na własność Kościoła przed 1230 rokiem (zapewne przed 1185 rokiem, a może jeszcze wcześniej, przy fundacji biskupstwa ${ }^{64}$. Katedra została zniszczona przez Krzyżaków w 1329 roku, nową zaś wzniesiono po 1340 roku na bardziej oddalonym od rzeki miejscu, później nazwanym Starym Miastem.

Stosunki Kazimierza Kujawskiego z biskupem Michałem są poświadczone przez kilkanaście dokumentów (Mitkowski 1968, s. 67 i nn.). Ich interpretacja bezpośrednio dotyczy problemu lokacji Włocławka, ale pozostawia wiele otwartych pytań. Na rzecz Michała książę zrezygnował w styczniu 1250 roku z roszczeń do patronatu nad prepozyturą katedralną. Dokument wystawił w biskupim Raciążku (Kajzer 1990, s. 28 i nn.) i działał za pośrednictwem kanclerza Wolimira i franciszkanina Mikołaja (KDPol. 1848, s. nr 45, s. 42-43). Prepozytem był w tym

${ }^{62}$ Opieram się głównie na pracy pt. „Włocławek. Dzieje miasta”, t. 1: „Od początków do 1918 roku" (1999).

${ }^{63}$ Ostateczna likwidacja miała miejsce w 1358 roku; w sprawie interpretacji osad św. Gotarda - por. Jasiński 2005, s. 165 i nn.

${ }^{64}$ Przemiany przestrzenne Włocławka zanalizował wnikliwie Janusz Bieniak (1999, s. 87-117); datuje on przekazanie Kościołowi okolic katedry po 1185 roku ze względu na brak wzmianki w dokumencie o tej darowiźnie. Przesłanka jest słaba i dotyczy raczej dochodów, a nie własności otoczenia katedry. W tekście jest mowa tylko o nowych nadaniach, w tym 10 donic miodu - de cellario eciam in veteri Wladislaw oraz 10 grzywien srebra - de foro eciam in novo Wladislaw, czyli Inowrocławia (KDPol. 1848, nr 2, s. 5). 
czasie kapelan i lekarz władcy - Mikołaj, który w pozbawionym daty dziennej dokumencie uzyskał prawo do lokacji na prawie niemieckim (na wzór Brześcia) wsi Sobota, należącej do uposażenia jego funkcji w kapitule. Wśród świadków nie było biskupa i kanoników (KDPol. 1848, nr 44, s. 41-42: Mitkowski 1968, s. 8065). W obszernym i szczegółowym przywileju immunitetowym z października 1250 roku, który poświadczał zawarty w Sieradzu kompromis między Kazimierzem a biskupem (za pośrednictwem arcybiskupa Pełki i biskupa wrocławskiego Tomasza), dawne podgrodzie zostało określone jako ciuitas kathedralis Wladeslauia, quantum territorium canonicorum occupat. Jak widać znajdowała się na nim katedra i domy kanoników, którym książę potwierdził własność opłat celnych na rzeczce Zgłowiączce - od targu Zgłowiączka aż do Wisły (a foro Zgouendie usque in Wislam ubicunque fluuius Zgouendia transeatur) oraz targowe $\mathrm{z}$ ich Włocławka (targowe de eadem Wladislauia), a także cło od statków płynących Wisłą (theloneo nauium per Wislam ibidem transeuncium) ${ }^{66}$. We Włocławku były dwa targi: kościelny i książęcy, nazwany Zgłowiączka. Określenie „miasto katedralne” i potwierdzenie praw do dochodów sugeruje, że nad Zgłowiączką, na południe od grodu, już istniało (lub było właśnie zakładane) miasto książęce, lokowane na prawie niemieckim. Jego powstawanie naruszało wcześniejsze i uzasadnione prawa Kościoła. Ugoda podcięła widocznie pomyślność tej lokacji. W 1255 roku Kazimierz Kujawski oddał nowemu biskupowi Wolimirowi (1252-1275) swoją civitas theutonicalis wraz z położonym obok (vicinius ciuitati) młynem na Zgłowiączce oraz dwoma wsiami - Wieniec i Łopacie, z prawem przeniesienia ich na prawo niemieckie. Zachował jedynie osadę ludzi zwanych Korabniki. Uzyskane wsie biskup mógł albo włączyć do miasta (sive civitati tali sepedicte agriculturam in eis adiciendi), albo zasiedlić kolonistami (KDPol. 1848, nr 68, s. 56-58). Spór został wznowiony w 1262 roku. Książę gwałtownie zareagował na budowę przez biskupa grodu w Raciążku. Z bulli Klemensa III z 1265 roku dowiadujemy się, że władca zawłaszczył znajdujące się w nim thesauros et alia bona ibidem inuenta oraz wyrzucił kanoników włocławskich z ich domów (decanum et canonicis Vladislauienses de ipsorum propriis domibus uiolenter eiecit) (Dokumenty kujawskie i mazowieckie 1888, nr 34, s. 204-205). Papież podtrzymał ekskomunikę rzuconą na księcia. Ugodę ogłoszono w kwietniu 1266 roku in antiqua Wladislauia, przez co należy rozumieć wówczas okolice katedry. Kazimierz w zamian za dwie wsie pod Brześciem i ulgi w dziesięcinie

${ }^{65}$ Autor identyfikuje prepozyta Mikołaja z Mikołajem z Polski, autorem dwóch traktatów lekarskich i lekarzem kolejnych książąt, w tym Leszka Czarnego i jego żony.

${ }^{66}$ Dalej w dokumencie jest mowa o ipsa Wladislauia, in qua ecclesia cathedralis sita est, prout ad canonicos eiusdem ecclesie noscitur pertinere (Dokumenty kujawskie i mazowieckie 1888, nr 18, s. 183-188). Nie należy targu Zgłowiączka (Zgouendia) identyfikować z Zgłowiączką, położoną wiele kilometrów w górę rzeczki. Trudno rozstrzygnąć, gdzie w 1253 roku Kazimierz wystawił dokument, w którym na prośbę biskupa Wolimira zwracał kościołowi w Kruszwicy połowę wsi Chełmce Małe - datum in Zgouendia, przypuszczam jednak, że chodzi o Włocławek (KDPol. 1848, nr 60, s. 50; Guldon, Powierski 1974, s. 40, 44, 128; Danielewski 2016, s. 137-138, 254-256). 
oddawał Drwały i Korabniki nad Wisłą wraz ze wszystkimi uży tkami - ita quod in omnibus fundis et locis circa ecclesiam kathedralem sytis, et in ambabus villis predictis, nihil sibi penitus iuris obtinuit. Książę przekazywał też młyn między Wieńcem (Winz) a molendinum ciuitatis Wladislauiensis. Zgadzał się także na obwarowanie tego miasta w przyszłości przez biskupów - dominus episcopus et eius successores, predictam ciuitatem fosssatis circumvallare ac munire ualeant lapidibus, lateribus siue lignis (KDPol. 1848, nr 89, s. 70-71). W datowanym na ten sam dzień innym dokumencie władca miał deklarować (pod karą 100 grzywien srebra w monecie), że sam zbuduje umocnienia wokół katedry: dicto episcopo ciuitatem in antiqua Wladislauia fossatis et plancis munire (Dokumenty kujawskie i mazowieckie 1888, nr 90, s. 72-74). Wyrok w sprawie ostatecznej ugody wydał rok później, we Wrocławiu na synodzie legackim kardynał Gwido (Dokumenty kujawskie i mazowieckie 1888, nr 36, s. 206-211) ${ }^{67}$.

Wolimir dążył do budowy biskupiego władztwa terytorialnego i to raczej on był teraz stroną ofensywną (Arnold 1921, s. 62 i nn.; Kaczmarczyk 1936, s. 307 i nn.; Matuszewski 1936, s. 442 i nn.). Planowanie budowy murów wskazuje, że zamierzał przekształcić Włocławek w duże miasto ${ }^{68}$. Kazimierz wprawdzie podjął rywalizację z Kościołem, ale się z niej musiał wycofać. Jeszcze przed ugodą nastąpiło przeniesienie siedziby kasztelanii do Brześcia Kujawskiego (KDW 1877, nr 177, s. 102-104; Urzędnicy kujawscy i dobrzyńscy 2014, s. 47, 124). Przyczynę rezygnacji przez księcia z Włocławka można wiązać nie tylko z okolicznościami politycznymi, ale także z rozwojem Inowrocławia. Już sama jego nazwa Novus Wladislaw, Vladizlav Iuvenis (zanotowana od 1185 roku) sugeruje związek z Włocławkiem (Biskup 1978, s. 130 i nn.). Współzależność jest jednoznaczna, ale jej wyjaśnienie może być tylko hipotetyczne. Zapewne było konsekwencją przenosin siedziby władzy książęcej czy zarządu prowincji. Już w 1185 roku wzmiankowany był w Inowrocławiu targ (KDPol. 1848, nr 2, s. 5; KDW 1877, nr 32, s. 38). Dla księcia Kazimierza, od początku panowania w 1231 roku, stanowił on centrum władzy, w którym wystawił kilkanaście dokumentów (Mitkowski 1968, s. 82 i nn. i według indeksu). Lokacja miasta na prawie niemieckim jest poświadczona jedynie pośrednio. Doszło do niej zapewne przed 1238 rokiem, kiedy wzmiankowany został klasztor Franciszkanów jako miejsce spisania ugody biskupa Michała ze Świętopełkiem pomorskim in juene Wladizlau in domo fratrum minorum. Tak wczesna fundacja klasztoru mendykanckiego (KDPol. 1848, nr 23, s. 18-20; Karczewski 2012, s. 155 i nn.) nie mogła funkcjonować w próżni i słusznie się ją wiąże z przeprowadzoną w tym czasie na nowym miejscu lokacją (Guldon 1968, s. 23; Biskup 1978, s. 137 i nn.; Danielewski 2016, s. 248-249, 259-260, 291-292,

${ }^{67}$ Książę miał zapłacić odszkodowanie arcybiskupowi gnieźnieńskiemu i biskupowi włocławskiemu po 200 grzywien, płockiemu - 50 grzywien.

${ }^{68} \mathrm{Już}$ w 1262 roku biskup wykupił prawa rycerskie do młyna na Zgłowiączce, związane z posiadaniem przez dziedziców Chalna drugiego brzegu rzeki (Dokumenty kujawskie i mazowieckie 1888 , nr 27, s. 200). 
305-306), paralelnie do Torunia i Płocka. Według zapiski w „Roczniku kapituły gnieźnieńskiej” pod 1239 rokiem książę pomorski Świętopełk exussit eccesiam de Wladislauia Iuveni et ipsam civitatem) (Rocznik kapituły gnieźnieńskiej 1962, s. 4). W 1263 roku zapisana została nazwa „stare miasto" (antiqua civitas), którą należy wiązać z targiem przy romańskim kościele NMP ${ }^{69}$. Obecny układ miasta jest późniejszy, ponieważ w nieznanym czasie miasto pierwszej lokacji uległo zapewne nowej regulacji przestrzennej (Biskup 1978, s. 143 i nn.; Frycz 1982, s. 417-487; ostatnio - Koc 2012, s. 67 i nn.). Problem wykracza jednak poza ramy niniejszych uwag.

Biskupi Włocławek został zniszczony przez Zakon podczas najazdu w 1329 roku. Nową lokację przeprowadził biskup w 1339 roku na wschód od dawnego, wzdłuż Wisły (Bieniak 1999, s. 87-117; Pakulski 1999, s. 118-138). Podsumowując można więc powiedzieć, że civitas kathedralis i konkurencyjne włocławskie targi przekształciły się w biskupie miasto komunalne, które pozostało jednak ośrodkiem o mniejszym znaczeniu, mimo korzystnego położenia nad spławną rzeką. W tym miejscu należy jeszcze wspomnieć o Lubuszu, który z wieloczłonowego zespołu osadniczego o charakterze wczesnomiejskim i siedziby biskupstwa zupełnie stracił po 1249/1250 roku znaczenie. W związku z lokacją pobliskiego Frankfurtu nad Odrą w 1253 roku spadł do roli miasteczka margrabiów brandenburskich (Kiersnowski, Kostrzewski, Wędzki 1967, s. 100-101; Historisches Ortslexikon 1983, s. 234 i nn.).

10. Z najbardziej zawikłaną sytuacją mamy do czynienia w Krakowie. Jej omówienie wymagałoby osobnej i drobiazgowej analizy. Biskup zajmował w Małopolsce szczególną pozycję polityczną i jego interesy nie mogły być w istotniejszy sposób bezpośrednio naruszone. Na Wawelu współżycie biskupa, kapituły i księcia często nie układało się dobrze, ale władcy nie zamierzali się z niego wycofać ze względu na stołeczne i symboliczne funkcje wzgórza (Banaszkiewicz 1998, s. 277 i nn.). Sprawdzonym sposobem na unikanie zasadniczych konfliktów w procesie lokacji było omijanie uprawnień własnościowych Kościoła poprzez przesuwanie nowego centrum. Pierwszą lokację Leszek Biały przeprowadził na przedpolu suburbium zwanego Okół. Okupił ją zapewne przywilejami dla dóbr biskupich i zgodą na rozwój w nich górnictwa (Kodeks dyplomatyczny katedry 1974, nr 12; Suchodolski 1987, s. 81 i nn.; Rajman 2012, s. 50 i nn.). W tym czasie największe znaczenie miał Sławków, położony na zachód od Krakowa (Pierzak 2002). W dokumencie wielkiej lokacji z 1257 roku znalazły się zapewnienia o zachowywaniu praw biskupa w Krowodrzy i na rzece Prądnik oraz zakaz przyjmowania chłopów - ne hac occasione nostra vel episcopalia aut canonicorumn vel aliorum predia ruralia desolentur (Przywileje ustanawiajace 2007, s. 25). Założeniu miasta towarzyszyło zagęszczenie kolejnych koncesji immunitetowych

${ }^{69}$ PU 1909, nr 188, s. 148: mieszkańcy w działkach zakonu krzyżackiego - coloni in areis fratrum in Juvene Wladislauia sive extra inter areas antique civitatis. 
na rzecz biskupstwa ${ }^{70}$, które konsekwentnie dążyło do uzyskania w swoich dobrach pełnych praw książęcych. Na obszarze Okołu utrzymała się własność Kościoła i możnych (Rajman 2004, s. 65 i nn.). Przypuszczam, że był to ważny czynnik przeszkadzający w połączeniu miasta komunalnego wielkiej lokacji z Wawelem. Stało się to możliwe po stłumieniu buntu przeciw panowaniu Leszka Czarnego, a więc po 1285 roku. Zagadnienie wiąże się z zawikłaną dyskusją wokół powstania tzw. nova civitas in Okol (ostatnio - Rajman 2004 s. 209 i nn.; Starzyński 2010, s. 51 i nn.; Słoń 2010, s. 288 i nn.; por. też Gawlas 1994, s. 101-11071). W każdym razie połączenie obwarowań komunalnego Krakowa $\mathrm{z}$ Wawelem przeprowadzone zostało jeszcze przed 1306 rokiem i ponownie, wraz z budową murów kamiennych, po stłumieniu buntu wójta Alberta (Gawlas 2000, s. 90 i nn.; Rajman 2012, s. 205 i nn.; Piekalski 2014, s. 88; ostatnio - Bunt wójta Alberta 2013). Scalenie przestrzeni miejskiej nie pociągnęło za sobą eliminowania własności Kościoła na Wawelu i ulicy Kanoniczej. Miasto lokacyjne zamieszkiwali jednak w przeważającej większości kupcy i rzemieślnicy (Rajman 2004, s. 342 i nn.). W późniejszym czasie udział duchowieństwa ponownie rósł, około 1580 roku wynosił (wraz z uniwersytetem) około 35\%, a stulecie później już ponad 55\% (Niwiński 1938, s. 549-584; Bieniarzówna, Małecki 1984, s. 13 i nn.).

Z powyższych uwag można wyciągnąć wniosek, że rywalizacja książąt z episkopatem i szerzej z duchowieństwem o udział w korzyściach z urbanizacji i gospodarki pieniężnej była niedocenianym, a bardzo istotnym elementem przemian ustrojowych, własnościowych i przestrzennych procesu lokacji w XIII wieku. Piastowie mogli odsunąć uprawnienia Kościoła i przejmować jedynie stopniowo, uprzywilejowując inne dobra biskupie oraz współdziałając z powstającymi gminami miejskimi. Czynników zmian było oczywiście wiele, a znaczącą rolę odgrywały przemiany religijności i państwowych funkcji Kościoła. Po wprowadzeniu reform gregoriańskich w Polsce malała zależność biskupów od książąt. Dawne nadania, niezbędne do wypełniania zadań politycznych przez episkopat, funkcjonowania liturgii i prac budowlanych, stawały się dla Piastów balastem. Biskupi byli konkurentami władców przy reorganizacji systemu dochodów i wprowadzaniu nowych zasad organizacji władzy terytorialnej, ponieważ oni również dążyli do ich zastosowania w swoich dobrach.

${ }^{70}$ Biskup w latach 1253-1258 otrzymał pięć przywilejów immunitetowych (Kaczmarczyk 1936, s. 94 i nn.; Matuszewski 1936, s. 189 i nn.; Gawlas 1997b, s. 391-401).

${ }^{71}$ Podtrzymuję większość zawartych w artykule opinii i zapowiadam ponowną analizę. 
Literatura

Wykaz skrótów

Civitas Posnaniensis - Civitas Posnaniensis. Studia z dziejów średniowiecznego Poznania, red. Z. Kurnatowska, T. Jurek, Poznań

Gniezno - Gniezno w świetle ostatnich badań archeologicznych. Nowe fakty, nowe interpretacje, red. Z. Kurnatowska, Poznań

KMP - Kronika Miasta Poznania, Poznań

Milicz - Milicz. Clavis Regni Poloniae. Gród na pograniczu, red. J. Kolenda, Wrocław

Włocławek. Dzieje - Włocławek. Dzieje miasta, red. J. Staszewski, t. 1: Od początków do 1918 roku, Włocławek

Wr.Ant. $\quad-$ Wratislavia Antiqua, Wrocław

Archeologia et historia

2004 Archeologia et historia urbana, red. R. Czaja i in., Elbląg.

Archeologia Gdańska

2006a Archeologia Gdańska, t. 1, red. H. Paner, Gdańsk.

2006b Archeologia Gdańska, t. 2, red. H. Paner, Gdańsk.

2007 Archeologia Gdańska, t. 3, red. H. Paner, Gdańsk.

2010 Archeologia Gdańska, t. 4, red. H. Paner, Gdańsk.

2013a Archeologia Gdańska, t. 5, red. H. Paner, Gdańsk.

2013b Archeologia Gdańska, t. 6, red. H. Paner, Gdańsk.

Archaeology in a town

2012 Archaeology in a town, a town in archaeology. Archeologia w mieście, miasto $w$ archeologii, Analecta Archaeologica Ressoviensia, red. A. Rozwałka, t. 7, Rzeszów.

Arnold S.

1921 Władztwo biskupie na grodzie wolborskim w wieku XIII, Warszawa.

Banaszkiewicz J.

1998 Polskie dzieje bajeczne mistrza Wincentego Kadlubka, Wrocław.

Bartoszewicz A. i H.

2010 Pultusk: obraz kartograficzny miasta od końca XV do początku XX wieku, Pułtusk.

Bieniak J.

1999 Powstanie miasta samorzadowego - najstarsze lokacje miejskie, [w:] Włocławek. Dzieje, s. 87-117.

Bieniarzówna J., Małecki J. M.

1984 Dzieje Krakowa. Kraków w wiekach XVI-XVIII, Kraków.

Bilska-Ciećwierz M.

2007 Powstanie i organizacja kapitut kolegiackich metropolii gnieźnieńskiej w średniowieczu, Kraków. 
Bischofs- und Kathedralstädte

1976 Bischofs- und Kathedralstädte des Mittelalters und der frühen Neuzeit, red. F. Petri, Köln/Wien.

Biskup M.

1978 Dzieje miasta w średniowieczu (od końca XII w. do 1466 r.), [w:] Dzieje Inowrocławia, red. M. Biskup, t. 1 (do 1919 r.), Warszawa-Poznań-Toruń, s. $129-236$.

Boshof E.

2007 Europa im 12. Jahrhundert. Auf dem Weg in die Moderne, Stuttgart. Broekmann T.

2005 Rigor iustitiae. Herrschaft, Recht und Terror im normannisch-staufischen Süden (1050-1250), Darmstadt.

Bruszewska-Głombiowska M.

2002 Biskup włocławski Michat. Działalność kościelna, gospodarcza, polityczna (1220-1252), Gdańsk.

Buczek K.

1964 Targi i miasta na prawie polskim (okres wczesnośredniowieczny), Wrocław.

1967 Sprawa lokacji miasta Płocka, Kwartalnik Historyczny, R. 74, z. 4, s. 10131030.

1970 Regalia, [w:] Stownik starożytności stowiańskich, t. 4: $P-R$, red. G. Labuda, Z. Stieber, Wrocław, s. 479-484.

1972 Powolowe - poradlne - podymne, Przegląd Historyczny, t. 63, z. 1, s. 1-30.

1975 Skarbowość: Polska, [w:] Stownik starożytności słowiańskich, t. 5: S-Ś, red. G. Labuda, Z. Stieber, Wrocław, s. 205-210.

2006 Studia z dziejów ustroju społeczno-gospodarczego Polski piastowskiej, t. 2, wyd. W. Bukowski, Kraków.

Bunt wójta Alberta

2013 Bunt wójta Alberta. Kraków i Opole we wzajemnych zwiąkach w XIV wieku, red. J. Rajman, Annales Universitatis Pedagogice Cracoviensis 133, Studia Historica 13, Kraków.

Buśko C.

2005 Wrocław u progu lokacji, [w:] Wschodnia strefa Starego Miasta we Wroctawiu w XII-XIV wieku. Badania na placu Nowy Targ, red. C. Buśko, Wrocław, s. $177-194$.

Buśko C., Goliński M., Kaczmarek M., Piątkowski L.

2001 Historia Wroctawia od pradziejów do końca czasów habsburskich, Wrocław. Cembrzyński P.

2011 Zaopatrzenie $w$ wodę i usuwanie nieczystości w miastach stref battyckiej i sudecko-karpackiej w XIII-XVI wieku, Wr.Ant. 14, Wrocław.

Chłopocka H.

1965a Gniezno głównym ośrodkiem polityczno-administracyjnym Wielkopolski do polowy XIII w., [w:] Dzieje Gniezna, red. J. Topolski, Warszawa, s. 118-132.

1965b Lokacja na prawie zachodnioeuropejskim. Rola Gniezna w procesie jednoczenia państwa, [w:] Dzieje Gniezna, red. J. Topolski, Warszawa, s. 133-156. 
Chorowska M.

2003 Rezydencje średniowieczne na Śląsku. Zamki, pałace, wieże mieszkalne, Wrocław.

2004 Zamek Królewski w Poznaniu na tle architektury zamków śląskich z okresu średniowiecza, [w:] Zamek książąt, królów, starostów, KMP, nr 4/2004, s. 7-26.

2005 Rozplanowanie średniowiecznego Poznania na tle miast ślaskich, [w:] Civitas Posnaniensis, s. 207-224.

2008 Zamek czy pałac? Ruina zamku w Miliczu na tle średniowiecznych siedzib biskupich w Europie, [w:] Milicz, s. 129-142.

2010 Regularna sieć ulic. Powstanie i przemiany do poczatku XIV w., [w:] Ulice średniowiecznego Wrocławia, Wr.Ant. 11, red. J. Piekalski, K. Wachowski, Wrocław, s. 67-89.

Chorowska M., Karst D., Lasota C.

1998 Organizacja przestrzenna produkcji i sprzedaży piwa w'średniowiecznej Świdnicy, Archaeologia Historica Polona, t. 7, s. 157-180.

Chorowska M., Lasota C.

2013 Kamienica mieszczańska w Świdnicy. Karczma i mieszkanie w XIII-XVIII w. Wrocław.

Chrzest $-\dot{s} w$. Wojciech

2016 Chrzest -św. Wojciech-Polska. Dziedzictwo średniowiecznego Gniezna. Katalog wystawy, red. T. Sawicki, Gniezno.

Cieśla I.

1958 Taberna wczesnośredniowieczna na ziemiach polskich, Studia Wczesnośredniowieczne, t. 4, s. 159-222.

Civitas Cholbergensis

2005 Civitas Cholbergensis. Transformacja kulturowa w strefie nadbattyckiej w XIII w., red. M. Rębkowski, Kołobrzeg.

Civitates principales

1998 Civitates principales. Wybrane ośrodki władzy w Polsce wczesnośredniowiecznej. Katalog wystawy, red. T. Janiak, D. Stryniak, Gniezno.

Codex diplomaticus

1912 Codex diplomaticus et epistolaris regni Bohemniae, red. G. Friedrich, t. 2 (1198-1230), Pragae.

Czerner O.

2002 Zabudowy rynków. Średniowieczne bloki śródrynkowe wybranych dużych miast Śląska, Wrocław.

Danielewski M.

2016 Sieć grodowa na Kujawach oraz jej funkcje od połowy X do końca XIII wieku, Poznań.

Dekański D.

1999 Początki zakonu dominikanów prowincji polsko-czeskiej: pokolenie św. Jacka w zakonie, Gdańsk. 
Dembiński P.

2003 Fundacja i erekcja kolegiaty św. Marii Magdaleny w Poznaniu, [w:] Stara i nowa fara, KMP, nr 3/2003, s. 63-75.

2005 Środowisko duchownych w średniowiecznym Poznaniu, [w:] Civitas Posnaniensis, s. 327-343.

Deptuła C.

1975 Kościót Płocki w XII wieku, [w:] Kościót płocki XI-XX wieku. Jubileuszowa ksiega pamiątkowa 900-lecia diecezji, red. J. Kłoczowski, Płock, s. 67-84.

Dokumenty kujawskie i mazowieckie

1888 Dokumenty kujawskie i mazowieckie przeważnie z XIII wieku, wyd. B. Ulanowski, Archiwum Komisji Historycznej Akademii Umiejętności, t. 4, Kraków.

Dygo M.

1993 „Hospites eciam eo iure fruantur quo et milites Mazouienses”. W sprawie lokacji Płocka w 1237 roku, Kwartalnik Historyczny, R. 100, z. 3, s. 3-17.

Escher M., Hirschmann F. G.

2005 Die urbanen Zentren des hohen und späteren Mittelalters. Vergleichende Untersuchungen zu Städten und Städtelandschaften im Westen des Reiches und im Ostfrankenreich, 1. 1.1: Thematischer Teil, Trier.

Europejskie miasta

2007 Europejskie miasta prawa magdeburskiego: tradycja, dziedzictwo, identyfikacja, red. A. Biedrzycka, A. Kutylak-Hapanowicz, Kraków.

Frycz J.

1982 Architektura i sztuka Inowrocławia, [w:] Dzieje Inowrocławia, red. M. Biskup, t. 2 (od 1919 r. do końca lat siedemdziesiatych), Poznań 1982, s. 417-487.

Garnier C.

2013 Die Macht des Machbaren: Staufische Politik im Spannungsfeld königlicher Herrschaft und fürstlicher Partizipation, [w:] Macht und Spiegel der Macht. Herrschaft in Europa im 12. und 13. Jahrhundert von der Hintergrund der Chronistik, red. N. Kersken, G. Vercamer, Wiesbaden, s. 235-253.

Gawarecki W. H.

1826 Wiadomość historyczna miasta Pułtuska, Warszawa.

Gawlas S.

1994 Nova civitas in Okol. Fragment z dziejów Krakowa, [w:] Społeczeństwo Polski średniowiecznej, t. 6, red. S. K. Kuczyński, Warszawa, s. 101-110.

1997a Polityka wewnętrzna Przemysła II a mechanizmy społecznych dązeń $i$ konfliktów w Wielkopolsce jego czasów, [w:] Przemyst II. Odnowienie Królestwa Polskiego, red. J. Krzyżaniakowa, Poznań, s. 65-80.

1997b Człowiek uwikłany w wielkie procesy-przykład Muskaty, [w:] Człowiek w społeczeństwie średniowiecznym, red. R. Michałowski i in., Warszawa, s. 391-401.

1999 Ulica a zmiany krajobrazu miejskiego w okresie lokacji, Kwartalnik Historii Kultury Materialnej, R. 49, z. 1-2, s. 3-25. 
2000 O ksztalt zjednoczonego Królestwa. Niemieckie władztwo terytorialne a geneza społeczno-ustrojowej odrębności Polski, wyd. 2, Warszawa.

2005 Przełom lokacyjny $w$ dziejach miast środkowoeuropejskich, [w:] Civitas Posnaniensis, s. 133-162.

2006 Komercjalizacjajako mechanizm europeizacji peryferii na przykładzie Polski, [w:] R. Czaja i in., Ziemie polskie wobec Zachodu. Studia nad rozwojem średniowiecznej Europy, Warszawa, s. 25-116.

2009 Die Zentrale Funktion der Städte in Ostmitteleuropa in der Zeit des Landesausbaus, [w:] Städtelandschaften im Ostseeraum im Mittelalter und in der frühen Neuzeit, red. R. Czaja, C. Jahnke, Toruń, s. 9-28.

2012 Chłopi $w$ Polsce piastowskiej przed kolonizacja na prawie niemieckim jako problem historiograficzny, Roczniki Historyczne, R. 78, s. 7-50.

2013 Das Problem der Fürstenmacht zur Zeit von Vincentius Kadtubek, [w:] Macht und Spiegel der Macht. Herrschaft in Europa im 12. und 13. Jahrhundert von der Hintergrund der Chronistik, red. N. Kersken, G. Vercamer, Wiesbaden, s. 273-308.

Gąsiorowski A.

1977 Źródła do dziejów Poznania XIV-XV w., [w:] Początki i rozwój Starego Miasta $w$ Poznaniu $w$ świetle badan archeologicznych $i$ urbanistyczno-architektonicznych, red. W. Błaszczyk, Warszawa, s. 475-477.

1988a Miasto późnośredniowieczne, [w:] Dzieje Poznania do roku 1793, t. 1, cz. 1, red. J. Topolski, Warszawa-Poznań, s. 209-232.

1988 b Rzemiosło $i$ handel, [w:] Dzieje Poznania do roku 1793, t. 1, cz. 1, red. J. Topolski, Warszawa-Poznań, s. 269-284.

Gieysztor A., Szaniawska W., Koczorowska-Pielińska E., Galicka J., Sygietyńska H., Sołtan A.

1980 Warszawa książęca, [w:] Warszawa, jej dzieje i kultura, Warszawa, s. 17-55. Gniezno

1995 Gniezno pierwsza stolica Polski, miasto świętego Wojciecha. Katalog wystawy, red. M. Wrońska-Idziak, M. Zielińska, Gniezno.

Goliński M.

1991 Podstawy gospodarcze mieszczaństwa wrocławskiego w XIII wieku, Wrocław.

1997 Socjotopografia późnośredniowiecznego Wrocławia (przestrzeń-podatnicy-rzemiosto), Wrocław.

2000a Ku rekonstrukcji pierwotnych funkcji Tyńskiego Dworu w Pradze, [w:] Średniowieczny Ślask $i$ Czechy. Centrum średniowiecznego miasta. Wrocław a Europa Środkowa, Wr.Ant. 2, red. J. Piekalski, K. Wachowski, Wrocław, s. $127-137$.

2000b Praski Tyn wobec skutków XIII-wiecznej transformacji miasta, [w:] Średniowieczny Ślask $i$ Czechy. Centrum średniowiecznego miasta. Wrocław a Europa Środkowa, Wr.Ant. 2, red. J. Piekalski, K. Wachowski, Wrocław, s. 139-145.

2000c Wokól socjotopografii późnośredniowiecznej Świdnicy, cz. 1, Wrocław. 2003 Wokół socjotopografii późnośredniowiecznej Świdnicy, cz. 2, Wrocław. 
2005a Miasta a polityka gospodarcza Henryka IV Probusa, [w:] Ślask w czasach Henryka IV Prawego, Wr.Ant. 8, red. K. Wachowski, Wrocław, s. 49-62.

2005 b Książe, biskup i zamki, [w:] Nie tylko zamki. Szkice ofiarowane profesorowi Jerzemu Rozpędowskiemu w siedemdziesiąta rocznicę urodzin, red. M. Chorowska i in., Wrocław, s. 41-53.

2012 Wokót problematyki formowania się stanu mieszczańskiego w Polsce, [w:] Studia z historii spolecznej, red. M. Goliński, S. Rosik, Scripta historica medievalia, t. 2, Wrocław, s. 7-76.

2013 Wstęp, [w:] Organizacja władz miejskich, s. 5-6.

Gołembiowski M.

1990 Lokacje miast na prawie chetmińskim, [w:] Studia Culmenisa historico-juridica czyli księga pamiątkowa 750-lecia prawa chetmińskiego, t. 1, red. Z. Zdrójkowski, Toruń, s. 282-285.

Gołembnik A.

2011 Rozwój osadnictwa otwartego i pierwsza lokacja miasta, [w:] Płock wczesnośredniowieczny, s. 217-278.

2015 Czego (i dlaczego) nie wiemy o przeszłości Płocka-zagadnienia wybrane, [w:] Archaeologica hereditas. Grody średniowiecznego Mazowsza. Księga poświęcona pamięci Marka Dulinicza, red. M. Żurek, M. Krasna-Korycińska, Warszawa-Zielona Góra, s. 147-158.

Grodecki R.

1921 Przywilej menniczy biskupstwa poznańskiego w r. 1232, Poznań.

Gromski J

1977 Kultura sanitarna Warszawy do końca XVIII w., Warszawa.

Guldon Z.

1968 Lokacje miast kujawskich i dobrzyńskich $w$ XIII-XV w., Ziemia Kujawska, t. 2, s. 19-46.

Guldon Z., Powierski J.

1974 Podziały administracyjne Kujaw i ziemi dobrzyńskiej w XIII-XIV wieku, Poznań.

Hirschmann F. G.

2011 Die Anfänge des Städtewesens In Mitteleuropa. Die Bischofssitze des Reiches bis ins 12. Jahrhundert, Stuttgart.

2013 Die Bischofstädte um 1150 - eine vergleichende Analyse mit Ausblick in die Zeit um 1200, [w:] Wandel der Stadt um 1200. Die bauliche und gesellschaftliche Transformation der Stadt im Hochmittelalter, red. K. Igel i in., Stuttgart, s. 67-80.

Historisches Ortslexikon

1983 Historisches Ortslexikon für Brandenburg, cz. 7: Lebus, oprac. P. P. Rohlrach, Weimar.

Igel K.

2013 Gesellschaftlicher Wandel-städtischer Wandel? Zur Formierung urbaner Gesellschaften im 12. Jahrhundert, [w:] Wandel der Stadt um 1200. Die bauliche und gesellschaftliche Transformation der Stadt im Hochmittelalter, red. K. Igel i in., Stuttgart, s. 31-46. 
Irgang W.

2003 Libertas ecclesiae und landesherrliche Gewalt-Vergleich zwischen dem Reich und Polen, [w:] Das Reich und Polen: Parallelen, Interaktionen und Formen der Akkulturation im hohen und späten Mittelalter, red. T. Wünsch, A. Patschovsky, Ostfildern, s. 93-127.

Janiak T., Strzyżewski C.

2001 Osadnictwo wczesnośredniowieczne na terenie Gniezna i w jego regionie, [w:] Gniezno, s. 45-85.

Jasiński T.

1999 Toruń XIII-XIV wieku - lokacja miast toruńskich i początki ich rozwoju (1231-około 1350), [w:] Historia Torunia, red. M. Biskup, t. 1: W czasach średniowiecza (do roku 1454), Toruń, s. 100-166.

2005 Uwarunkowania lokacji Poznania, [w:] Civitas Posnaniensis, s. 163-172. Johansen P.

1965 Die Kaufmannskirche, [w:] Die Zeit der Stadtgründung im Ostseeraum, red. M. Stenberger, Visby, s. 85-134.

Jurek T.

2003 Wokół zagadek najdawniejszych dziejów poznańskiej fary, [w:] Stara i nowa fara, KMP, nr 3/2003, s. 46-62.

2005 Przebieg lokacji Poznania, [w:] Civitas Posnaniensis, s. 173-191.

2006 Dziedzic Królestwa Polskiego książę głogowski Henryk (1274-1309), Kraków.

2011 Pismo w życiu społecznym Polski późnego średniowiecza, [w:] Historia społeczna późnego średniowiecza. Nowe badania, red. S. Gawlas, M. T. Szczepański, Warszawa, s. 203-231.

2015 Rozwój dokumentu polskiego w XIII wieku, [w:] Dyplomatyka staropolska, red. T. Jurek, Warszawa, s. 88-144.

Kaczmarczyk Z.

1936 Immunitet sadowy i jurysdykcja poimmunitetowa $w$ dobrach Kościoła $w$ Polsce do końca XIV wieku, Poznań.

1953 Przywilej lokacyjny dla Poznania z r. 1253, [w:] Studia poznańskie ku uczczeniu 1000-lecia miasta i 700-lecia samorządu miejskiego (połowa Xw., 1253-1953), oprac. M. Suchocki, Z. Wojciechowski, Poznań, s. 142-166.

Kajzer L.

1990 Zamek $w$ Raciążku, Budownictwo obronno-rezydencjonalne Kujaw i ziemi dobrzyńskiej, cz. 1, Łódź.

Kaniewski A.

2004 Poznań. Dzieje miasta woda pisane, Poznań.

Kara M.

2006 Tron książęcy ad Sanctam Mariam w Poznaniu w świetle ponownych dociekań analitycznych, Slavia Antiqua, t. 47, s. 99-160.

Karczewski D.

2012 Franciszkanie w monarchii Piastów i Jagiellonów w średniowieczu. Powstanie - rozwój-organizacja, Kraków. 
Karst D.

2002 Technologia rzemieślniczej produkcji piwa we Wrocławiu w okresie średniowiecznym i nowożytnym na tle browarnictwa europejskiego, [w:] Piwo we Wrocławiu od średniowiecza po czasy współczesne, red. H. Okólska, Wrocław, s. 9-43.

Kazimierski K.

1975 Przegląd źródet historycznych do dziejów Puttuska, [w:] Puttusk. Studia i materiaty z dziejów miasta i regionu, t. 2, red. B. Gierlach, A. Gieysztor, B. Kotarski, Warszawa, s. 11-26.

KDKM

1863 Kodeks dyplomatyczny księstwa mazowieckiego, wyd. J. T. Lubomirski, Warszawa.

KDPol.

1848 Kodeks dyplomatyczny Polski, t. 2, wyd. L. Rzyszczewski, A. Muczkowski, J. Bartoszewicz, Warszawa.

KDW

1877 Kodeks dyplomatyczny Wielkopolski, t. 1, wyd. I. Zakrzewski, Poznań.

1878 Kodeks dyplomatyczny Wielkopolski, t. 2, wyd. I. Zakrzewski, Poznań.

1982 Kodeks dyplomatyczny Wielkopolski, t. 6, wyd. A. Gąsiorowski, H. Kowalewicz, Warszawa-Poznań.

Kejr̆ $\mathrm{J}$.

1969 Zwei Studien über die Anfänge der Städteverfassung in den böhmischen Ländern, II. Privileg des Herzogs Sobieslaw II. für die Prager Deutschen, Historica 16, s. 116-142.

1998 Vznik městského zř́zení v českýh zemích, Praha.

2006 Aus Böhmens Verfassungsgeschichte. Staat-Städtewesen-Hussitentum, Praha.

Kiersnowski R., Kostrzewski B., Wędzki A.

1967 Lubusz, [w:] Słownik starożytności słowiańskich, t. 3: L-O, red. W. Kowalenko, G. Labuda, Z. Stieber, Wrocław, s. 100-101.

Kłoczowski J.

2008 Polska prowincja dominikańska w średniowieczu i Rzeczypospolitej obojga (wielu) narodów, Poznań.

2010 Wspólnoty zakonne w średniowiecznej Polsce, Lublin.

Koc S.

2010 Inowrocław, Krzyżacy a zjednoczenie Królestwa Polskiego, Inowrocław. Kodeks dyplomatyczny katedry

1874 Kodeks dyplomatyczny katedry krakowskiej św. Wactawa, cz. 1, wyd. F. Piekosiński, Kraków.

Kołobrzeg

2007 Kołobrzeg. Wczesne miasto nad Bałtykiem, red. L. Leciejewicz, M. Rębkowski, Warszawa.

Kowalska A. B., Dworaczek M.

2011 Szczecin wczesnośredniowieczny: nadodrzańskie centrum, Warszawa. 
Kóčka-Krenz H.

2003 Dzieje Ostrowa Tumskiego w Poznaniu przed lokacją miasta, [w:] W kręgu katedry, KMP, nr 1/2003, s. 7-26.

2014 Poznański gród ksiązęcy na nadwarciańskiej wyspie, [w:] Warta, KMP, nr 1/2014, s. 43-52.

Kraków

2014 Kraków romański, red. M. Bochenek, Kraków.

Kraków europejskie miasto

2007 Kraków europejskie miasto prawa magdeburskiego 1257-1791. Katalog wystawy, red. G. Lichończak-Nurek, Kraków.

Kraków w chrześcijańskiej Europie

2006 Kraków w chrześcijańskiej Europie X-XIII w. Katalog wystawy, red. E. Firlet, E. Zaitz, Z. Miśtal, Kraków.

Krasnowolski B.

2004 Lokacyjne układy urbanistyczne na obszarze ziemi krakowskiej w XIII i XIV w., Kraków.

2006 Wzorce lokacyjnych układów urbanistycznych $w$ Małopolsce: stan i metody badań, postulaty badawcze, próba syntezy, [w:] Procesy lokacyjne miast w Europie środkowo-wschodniej, red. C. Buśko, M. Goliński, B. Krukiewicz, Wrocław, s. 65-137.

Krut-Horonziak O.

1998 Wczesnośredniowieczny Włocławek, [w:] Civitates principales. Wybrane ośrodki władzy w Polsce wczesnośredniowiecznej. Katalog wystawy, red. T. Janiak, D. Struniak, Gniezno, s. 108-111.

Kujawski W.

1999 Włocławek - stolica biskupstwa, [w:] Włocławek. Dzieje, s. 36-72.

Kundel R.

2006 Architektura gotycka na Mazowszu, Warszawa.

Kuraś S.

1971 Przywileje prawa niemieckiego miast $i$ wsi małopolskich XIV-XV wieku, Wrocław.

Kutrzeba S.

1898 Piwo w średniowiecznym Krakowie, Rocznik Krakowski, t. 1, s. 37-52.

Kühler W.

1964 Das Bannmeilenrecht. Ein Beitrag der mittelalterlichen Ostsiedlung zur wirtschaftlichen und rechtlichen Verschränkung von Stadt und Land, Würzburg.

Kürbis B.

1988 Kultura wczesnego Poznania: twórcy, opiekunowie, uczestnicy, [w:] Dzieje Poznania do roku 1793, t. 1, cz. 1, red. J. Topolski, Warszawa-Poznań, s. 101-133.

Lalik T.

1975 Funkcje miast i miasteczek w Polsce późniejszego średniowiecza, Kwartalnik Historii Kultury Materialnej, R. 23, nr 4, s. 551-565. 
1976 Geneza sieci miasteczek w Polsce średniowiecznej, [w:] Miasta doby feudalnej w Europie środkowo-wschodniej, red. A. Gieysztor, T. Rosłanowski, Warszawa-Poznań-Toruń, s. 113-136.

Linette E.

1981 Zamek w Poznaniu. 700 lat dziejów, Poznań.

Luciński J.

1990 Przywilej chetmiński z 1233 r., jego treść oraz dzieje jego postanowień, [w:] Studia Culmenisa historico-juridica czyli Ksiega pamiątkowa 750-lecia prawa chetmińskiego, red. Z. Zdrójkowski, Toruń, s. 81-139.

Lübke C.

2001 Fremde im östlichen Europa. Von Gesellschaften ohne Staat zu verstaatlichen Gesellschaften (9.-11. Jahrhundert), Köln.

Lück H.

2009 Zur Gerichtsverfassung in den Mutterstädten des Magdeburger und Lübecker Rechts, [w:] Grundlagen für ein neues Europa. Das Magdeburger und Lübecker Recht in Spätmittelalter und Früher Neuzeit, red. H. Lück, M. Puhle, A. Ranft, Köln, s. 163-181.

Łodyński M.

1908 O interpolacjach $w$ dokumentach biskupstwa płockiego, [w:] Studya historyczne wydane ku czci prof. W. Zakrzewskiego, Kraków, s. 301-315.

1919 Falsyfikaty wśród dokumentów biskupstwa płockiego w XIII wieku. Studium historyczno-dyplomatyczne, Kraków.

Magdeburg

2005 Magdeburg. Die Geschichte der Stadt 805-2005, red. M. Hettenhorst, Dössel, s. $137-153$.

Magdeburger Recht

1989 Magdeburger Recht, red. F. Ebel, t. 2: Die Rechtsmitteilungen und RechtsMaciakowska Z. sprüche für Breslau, cz. 1: Die Quellen von 1261 bis 1452, Köln.

2011 Ksztaltowanie przestrzeni miejskiej Głównego Miasta w Gdańsku do początku XV wieku, Gdańsk.

Małachowicz E.

1992 Wrocław na wyspach. Rozwój urbanistyczny i architektoniczny, wyd. 2, Wrocław.

1993 Wrocławski zamek książęcy i kolegiata św. Krzyża na Ostrowie, Wrocław.

1994 Książęce rezydencje, fundacje i mauzolea w lewobrzeżnym Wrocławiu, Wrocław.

Małachowicz M.

2000 Zagadnienie najstarszego kościoła św. Wojciecha we Wrocławiu, [w:] Ślask około roku 1000, red. M. Małachowicz, M. Młynarska-Kaletynowa, Wrocław, s. 189-193.

Manikowska H.

2000 Princeps fundator w przedlokacyjnym Wrocławiu. Od Piotra Włostowica do Henryka Brodatego, [w:] Fundacje i fundatorzy w średniowieczu i epoce nowożytnej, red. E. Opaliński, T. Wiślicz, Warszawa, s. 37-57. 
Maroszek J.

1990 Targowiska wiejskie $w$ Koronie Polskiej $w$ drugiej połowie XVII $i$ w XVIII wieku, Białystok.

Matuszewski J.

1936 Immunitet ekonomiczny $w$ dobrach Kościoła w Polsce do roku 1381, Poznań. Mikulski K.

1996 Problem tzw. „wyspy“ "toruńskiej w świetle źródet podatkowych z końca XIV i pierwszej połowy XV wieku, Zapiski Historyczne, t. 61, z. 1, s. 7-24.

1999 Przestrzeń i społeczeństwo Torunia od końca XIV do początku XVIII wieku, Toruń.

Mitkowski J.

1960 Sprawa interpolacji w dokumencie Konrada Mazowieckiego dla biskupstwa płockiego z roku 1231, [w:] Mediaevalia w 50 rocznice pracy naukowej Jana Dabrowskiego, red. J. Garbacik i in., Warszawa, s. 39-51.

1968 Kancelaria Kazimierza Konradowica, księcia kujawsko-łęczyckiego 12331267, Wrocław.

Młynarska-Kaletynowa M.

1986 Wrocław w XII-XIII wieku. Przemiany społeczne i osadnicze, Wrocław.

1995 Przemiany przestrzenne Wrocławia $w$ wiekach XII-XIII, [w:] Architektura Wrocławia, t. 2: Urbanistyka, red. J. Rozpędowski, E. Różycka, J. Urbanik, Wrocław, s. 9-26.

Modzelewski K.

1987 Chłopi w monarchii wczesnopiastowskiej, Wrocław.

Możejko B., Kaczor D., Śliwiński B.

2006 Zarys dziejów klasztoru dominikańskiego w Gdańsku od średniowiecza do czasów nowożytnych (1226/12127-1835), [w:] Archeologia Gdańska, s. $137-214$.

Moździoch S.

2002 Castrum munitissimum Bytom: lokalny ośrodek władzy w państwie wczesnopiastowskim, Warszawa.

Münch H.

1946 Geneza rozplanowania miast wielkopolskich XIII i XIV wieku, Kraków.

Nawrolska G.

2012 Początki Elbląga w świetle źródeł archeologicznych, Elbląg.

Niwiński M.

1938 Stanowy podzial własności nieruchomej w Krakowie XVI i XVII stulecia, [w:]

Studia historyczne ku czci Stanisława Kutrzeby, t. 2, Kraków, s. 549-584.

NKDMaz.

1989 Nowy kodeks dyplomatyczny Mazowsza, t. 2: Dokumnety z lat 1248-1355, wyd. I. Sułkowska-Kuraś, S. Kuraś, współprac. K. Pacuski, H. Wajs,Warszawa.

2000 Nowy kodeks dyplomatyczny Mazowsza, t. 3: Dokumenty z lat 1356-1381, wyd. 1. Sułkowska-Kuraś, S. Kuraś, współpraca J. Piętka, Warszawa. 
Nowacki B.

2003 Przemyst I: syn Władysława Odonica, książe wielkopolski 1220/1221-1257, Poznań.

Nowowiejski A. J.

1930 Płock. Monografia historyczna, Płock.

Okólska H.

2002 Wrocławski cech karczmarzy w okresie od 2 pot. XIII do końca XVIII w., [w:] Piwo we Wrocławiu od średniowiecza po czasy współczesne, red. H. Okólska, Wrocław, s. 47-57.

Organizacja władz miejskich

2013 Organizacja władz miejskich na obszarze Pierwszej Rzeczpospolitej i na Śląsku w XIII-XVIII w., red. M. Goliński, K. Mikulski, Toruń.

Ossowski W.

1999 Studia nad łodziami jednopiennymi z obszaru Polski, Gdańsk.

2010 Przemiany $w$ szkutnictwie rzecznym w Polsce. Studium archeologiczne, Gdańsk.

Pakulski J.

1999 Władze i społeczność miejska $w$ dobie polokacyjnej (XIV-XVw.), [w:] Włocławek. Dzieje, s. 118-138.

Paroń A.

2008 Ugoda w sprawie kasztelanii milickiej (26 VI 1249), [w:] Milicz, s. 97-128.

Paszkiewicz B.

2009 Brakteaty - pieniądz średniowiecznych Prus, Wrocław.

Pauk M.

2010 Moneta episcopalis. Mennictwo biskupie w Europie Środkowej X-XIII w. i jego zachodnioeuropejski kontekst, Przegląd Historyczny, t. 101, z. 4, s. 539-571.

Pauk M., Wółkiewicz E.

2012 Struktury administracyjne Śląska jako czynnik spójności prawnoustrojowej (XII-XV w.), Śląski Kwartalnik Historyczny Sobótka, t. 67, z. 4, s. 53-77.

2013 The administrative structure of Silesia as a determinant of legal and constitutional cohesion (12 $2^{\text {th }}-15^{\text {th }}$ century), [w:] Cuius regio? Ideological and territorial cohesion of the historical region of Silesia (c. 1000-2000), t. 1: The long formation of the region Silesia (c. 1000-1526), red. L. Harc, P. Wiszewski, R. Żerelik, Wroclaw, s. 65-91.

Pawlak P.

2005 Cmentarzyska przedlokacyjnego Poznania, [w:] Civitas Posnaniensis, s. 59-109.

Pela W.

1992 Rynek $w$ Puttusku w świetle źródet archeologicznych, Kwartalnik Historii Kultury Materialnej, R. 40, z. 3, s. 347-358.

1997 Badania archeologiczno-architektoniczne miasta Pultuska $w$ latach 1978-1984, [w:] Puttusk. Studia i materiały z dziejów miasta i regionu, t. 3, red. A. Gieysztor i in., Warszawa-Pułtusk, s. 41-54. 
2000 Stare Miasto w Pultusku w świetle źródet archeologiczno-architektonicznych, [w:] Pułtusk. Studia i materiaty z dziejów miasta i regionu, t. 4, red. H. Samsonowicz, Pułtusk, s. 11-34.

Pelczar S.

2013 Władysław Odonic: książę wielkopolski, wygnaniec i protektor Kościoła (ok. 1193-1239), Kraków.

Pianowski Z.

1994 „Sedes regni principales”. Rezydencje piastowskie do połowy XIII wieku na tle europejskim, Kraków.

Piekalski J.

1999 Od Kolonii do Krakowa. Przemiana topografii wczesnych miast, Wrocław.

2004 Wczesne domy mieszczan w Europie Środkowej. Geneza-funkcja-forma, Wrocław.

2005 Wrocław - miasto Henryka IV, [w:] Śląsk w czasach Henryka IV Prawego, Wr.Ant. 8, red. K. Wachowski, Wrocław, s. 39-48.

2010 Struktura osadnicza i drogi Wrocławia przed wytyczeniem regularnej sieci ulic, [w:] Ulice średniowiecznego Wrocławia, red. J. Piekalski, K. Wachowski, Wr.Ant. 11, Wrocław, s. 47-55.

2014 Praga, Wrocław i Kraków. Przestrzeń publiczna i prywatna w czasach średniowiecznego przełomu, Wrocław.

Pierzak J.

2002 Zamek biskupów krakowskich w Stawkowie, Bytom.

Plock

2011 Płock wczesnośredniowieczny, red. A. Gołembnik, Warszawa.

Polak Z.

2001 Lokacje płockie w świetle archeologii, Rocznik Mazowiecki, t. 13, s. 24-39.

2008 Raz jeszcze o trzynastowiecznej lokacji Płocka, [w:] Przez granice czasu. Księga jubileuszowa poświęcona profesorowi Jerzemu Gąsowskiemu, red. A. Buko, W. Duczko, Pułtusk, s. 223-228.

2011 Płock średniowieczny - kontynuacja czy nowa jakość?, [w:] Płock, s. 311-376. Przemyśl

2010 Przemyśl wczesnośredniowieczny, red. E. Sosnowska, Warszawa. Przywileje miasta

1994 Przywileje miasta Poznania XIII-XVIII wieku, wyd. W. Maisel, Poznań. Przywileje ustanawiające

2007 Przywileje ustanawiajace gminy miejskie wielkiego Krakowa (XIII-XVIII wiek), oprac. B. Wyrozumska, Kraków.

PU

1909 Preußisches Urkundenbuch, oprac V. A. Serphin, t. 1, cz. 2, Königsberg, Rabęcka-Brykczyńska I.

1964 Karczma, [w:] Słownik starożytności słowiańskich, t. 2: F-K, red. W. Kowalenko, G. Labuda, T. Lehr-Spławiński, Wrocław, s. 373-375.

1974 Jatki rzeźnicze w Polsce w XIII-XIV wieku, [w:] I. Rębacka-Brykczyńska, T. Sobczak, Z problematyki badań nad produkcja i konsumpcja żywności w Polsce, Wrocław, s. 7-130. 
Radzimiński A.

1999 Kapituła i duchowieństwo katedralne w średniowiecznym Włocławku, [w:] Włocławek. Dzieje, s. 73-86.

Rajman J.

2004 Kraków: zespół osadniczy, proces lokacji, mieszczanie do roku 1333, Kraków.

2012 Krakowska civitas sołtysów Piotra i Salomona, [w:] Społeczeństwo Polski średniowiecznej. Zbiór studiów, t. 12, red. S. Górzyński, Warszawa, s. 47-68.

Ratajczak T.

2008a Medieval architecture of the royal castle in Poznań, Quaestiones Medii Aevi Novae, t. 13, s. 219-242.

2008b Średniowieczny zamek królewski w Poznaniu. Uwagi na temat chronologii i genezy architektury, [w:] Przemystowie Wielkopolscy od księcia dzielnicowego do króla Polski, red. H. Kóčka-Krenz, Poznań, s. 33-54.

Rechts- und Sprachtransfer

2008 Rechts- und Sprachtransfer in Mittel und Osteuropa. Sachsenspiegel und Magdeburger Recht, red. E. Eichler, K. Lück, Berlin.

Rębkowski M.

2001 Pierwsze lokacje miast $w$ księstwie zachodniopomorskim. Przemiany przestrzenne i kulturowe, Kołobrzeg.

Rocznik kapituły gnieźnieńskiej

1962 Rocznik kapituły gnieźnieńskiej 1192-1247, [w:] Roczniki wielkopolskie, wyd. B. Kürbis, Monumenta Poloniae Historica, nova series, t. 6, Warszawa, s. $1-20$.

Rocznik kapituly poznańskiej

1962 Rocznik kapituly poznańskiej 965-1309, [w:] Roczniki wielkopolskie, wyd. B. Kürbis, Monumenta Poloniae Historica, nova series, t. 6, Warszawa, s. 21-109.

Rogalanka A.

1977 O układzie $i$ wielkości parcel $w$ średniowiecznym Poznaniu (Próba rozpoznania problemu), [w:] Poczatki i rozwój Starego Miasta w Poznaniu $w$ świetle badań archeologicznych i urbanistyczno-architektonicznych, red. W. Błaszczyk, Poznań, s. 323-376.

1988 Lokacja miasta na lewym brzegu Warty w 1253 roku, [w:] Dzieje Poznania do roku 1793, t. 1, cz. 1, red. J. Topolski, Warszawa-Poznań, s. 146-163.

Rojkowska H.

2014 Odkrycia przed kościołem Dominikanów w Krakowie, [w:] Kraków, s. $105-120$.

Rozpędowski J.

1995 Wrocław pierwszej lokacji, [w:] Architektura Wrocławia, t. 2: Urbanistyka, red. J. Rozpędowski, E. Różycka, J. Urbanik, Wrocław, s. 41-51.

Rozwałka A., Niedźwiadek R., Stasiak M.

2006 Lublin wczesnośredniowieczny. Studium rozwoju przestrzennego, Warszawa. 
Rutkowska-Płachcińska A.

1962 Gmina miejska w poczatkach XIII w. w Polsce, [w:] Wieki średnie-medium aevum. Prace ofiarowane Tadeuszowi Mantteuflowi w 60 rocznice urodzin, red. A. Gieysztor, M. H. Serejski, S. Trawkowski, Warszawa, s. 143-150.

1978 Urządzenia mlyńskie, przetwórstwo $i$ wyrób artykułów spożywczych, organizacja sprzedaży, [w:] Historia kultury materialnej Polski, t. 2: Od XII do $X V$ wieku, red. A. Rutkowska-Płachcińska, Wrocław, s. 180-203.

Rynek wroctawski

2001 Rynek wrocławski w świetle badań archeologicznych, cz. 1, red. C. Buśko, Wr.Ant. 3, Wrocław.

2002 Rynek wrocławski w świetle badań archeologicznych, cz. 2, red. J. Piekalski, Wr.Ant. 5, Wrocław.

Salina A.

2011 Polityka książąt mazowieckich wobec władz Kościoła od początku XIV wieku do 1526 roku, Poznań.

Salsa Cholbergensis

2000 Salsa Cholbergensis. Kołobrzeg wśredniowieczu, red. L. Leciejewicz, M. Rębkowski, Kołobrzeg.

Samsonowicz H.

2014 Szkice o mieście średniowiecznym, Warszawa.

Sawicki T.

2001a Badania przy kościele św. Jerzego w Gnieźnie, [w:] Gniezno, s. 163-185.

2001b Pracownia romańskiej ceramiki architektonicznej na Górze Lecha, [w:] Gniezno, s. 187-218.

2001c Z Zadań nad zamkiem książęcym na Górze Lecha w Gnieźnie, [w:] Gniezno, s. 221-241.

2016 Gniezno. Centrlany ośrodek państwa wczesnopiastowskiego w świetle badań archeologicznych, [w:] Chrzest - s'w. Wojciech, s. 59-104.

Schlesisches Urkundenbuch

1971 Schlesisches Urkundenbuch, t. 1: 971-1230, oprac. H. Appelt, Graz.

1977 Schlesisches Urkundenbuch, t. 2: 1231-1250, oprac. W. Irgang, Wien.

1984 Schlesisches Urkundenbuch, t. 3: 1251-1266, oprac. W. Irgang, Graz.

Schulz K.

1992 „Denn sie lieben die Freiheit so sehr...” Kommunale Aufstände und Entstehung des Europäischen Bürgertums im Hochmittelalter, Darmstadt.

Sikora F.

1969 Dokumenty i kancelaria Przemysła I oraz Bolesława Pobożnego 1239-1279 na tle współczesnej dyplomatyki wielkopolskiej, Wrocław.

Sikorski C.

1995 Uwagi o gnieźnieńskim zamku arcybiskupim, [w:] Gniezno. Studia i materiały historyczne, t. 4, red. J. Topolski i in., Poznań, s. 247-266.

Skierska I.

2003 Obowiązek mszalny w średniowiecznej Polsce, Warszawa. 
Słoń M.

2000 Szpitale średniowiecznego Wrocławia, Warszawa.

2006a Sukiennictwo w Europie Środkowej i wrocławskie nowe miasto, Śląski Kwartalnik Historyczny Sobótka, t. 61, z. 2, s. 211-223.

2006b Fundatio civitatis. Program fundacyjny procesu lokacyjnego na przykładzie Wrocławia, Krakowa i Poznania, [w:] Procesy lokacyjne miast w Europie środkowo-wschodniej, red. C. Buśko, M. Goliński, B. Krukiewicz, Wrocław, s. 227-245.

2007 Początki osady walońskiej i kościoła św. Maurycego we Wrocławiu, [w:] Dzieje parafii św. Maurycego na Przedmieściu Oławskim we Wrocławiu. Od początku osady walońskiej-poprzez czas Festung Breslau-do współczesności, red. R. Żerelik, Wrocław, s. 11-20.

2010 Miasta podwójne i wielokrotne w średniowiecznej Europie, Wrocław.

Soroka E.

1990 Romańskie plytki ceramiczne z Gniezna, [w:] Gniezno. Studia i materiaty historyczne, t. 3, red. M. Zielińska, Poznań, s. 59-101.

Sowina U.

2009 Woda i ludzie w mieście późnośredniowiecznym i wczesnonowożytnym. Ziemie

Spież J. A. OP polskie z Europa w tle, Warszawa.

2003 Początki klasztoru w Gdańsku na tle najstarszych fundacji dominikańskich, [w:] Dominikanie. Gdańsk-Polska-Europa, red. D. A. Dekański, A. Gołembnik, M. Grubka, Gdańsk-Pelplin, s. 167-184.

2004 Dominikanie w Poznaniu, [w:] Nasi dominikanie, KMP, nr 3/2004, s. 7-19. Spominki

1996 Spominki Płockie, [w:] Rocznik Świętokrzyski, wyd. A. Rutkowska-Płachcińska, Monumenta Poloniae Historica, nova series, t. 12, Kraków, s. 127-129.

Stan badań

2009 Stan badań archeologicznych miast $w$ Polsce, red. H. Paner, M. Fudziński, Starnawska M.

Z. Borcowski, Gdańsk.

1999 Między Jerozolima a Łukowem. Zakony krzyżowe na ziemiach polskich w średniowieczu, Warszawa.

Starzyński M.

2010 Civitas nostra cracoviensis. Szkic do polityki miejskiej Kazimierza Wielkiego, [w:] Kazimierz Wielki: historia i tradycja, red. M. Jaglarz, Rocznik Niepołomicki, t. 2, Niepołomice, s. 37-100.

Stawski M.

2010 Skryptorium czerwińskie jako miejsce powstania rękopisów liturgicznych norbertanek płockich. Uwagi o związach dwóch klasztorów kanonikatu regularnego na Mazowszu, [w:] Sanctimoniales. Zakony żeńskie w Polsce i Europie Środkowej (do przełomu XVIII i XIX wieku), red. A. Radzimiński, D. Karczewski, Z. Zyglewski, Bydgoszcz, s. 469-480. 
Stelmach R.

2012 Co mówia o karczmach średniowieczne dokumenty śląskie?, [w:] Kościót i społeczeństwo. Studia nad obiegiem informacji i konfliktach zbrojnych w dawnych i nowych wiekach, red. J. Grabowski, Warszawa, s. 77-91.

Studia średniowieczne

2006 Tadeusz Lalik, Studia średniowieczne, wybrał S. Trawkowski, Warszawa.

Suchodolska E.

1980 Regesty dokumentów mazowieckich z lat 1248-1345, Warszawa-Łódź.

2006 Dzieje polityczne (połowa XIII-połowa XIV w.), [w:] Dzieje Mazowsza, t. 1, Suchodolski S. red. H. Samsonowicz, Pułtusk, s. 213-256.

1987 Moneta możnowładcza i kościelna w Polsce wczesnośredniowiecznej, Wrocław.

Szacherska S. M.

1960 Opactwo cystersów w Szpetalu a misja pruska, Warszawa.

1978 Złoty wiek miasta 1495-1580, [w:] Dzieje Płocka, wyd. 2, red. A. Gieysztor, Płock, s. 126-179.

1992 Płock - civitas vetus czy civitas cathedralis?, [w:] Społeczeństwo Polski średniowiecznej. Zbiór studiów, t. 5, red. S. K. Kuczyński, Warszawa, s. 175-188.

Szulc A.

2016 Z inspiracji księżnej Jolenty. Klasztory franciszkanów i klarysek $w$ średniowiecznym Gnieźnie, [w:] Chrzest-św. Wojciech, s. 157-173.

Szyma M.

2011 Architektura sakralna Płocka w XIII w. - kolegiata św. Michała i kościót Szymaniak M.

św. Dominika, [w:] Plock, s. 279-310.

2007 Biskup płocki Gedko (1206-1223). Działalność kościelno-polityczna na tle Szymańska M. procesu emancypacji Kościoła polskiego spod władzy książęcej, Toruń.

1953 Wójtostwo poznańskie 1253-1386, [w:] Studia poznańskie ku uczczeniu 1000-lecia miasta i 700-lecia samorzadu miejskiego (połowa X w., 12531953), oprac. M. Suchocki, Z. Wojciechowski, Poznań, s. 167-193.

Teterycz-Puzio A.

2012 Na rozstajnych drogach. Mazowsze a Małopolska w latach 1138-1313, Słupsk.

Thieme A.

2001 Die Burggrafschaft Altenburg. Studien zu Amt und Herrschaft im Übergang vom hohen zum späten Mittelalter, Leipzig.

Topolski J.

1965 Gniezno miastem wielkich jarmarków, [w:] Dzieje Gniezna, red. J. Topolski, Warszawa, s. 260-324.

Trawkowski S.

1958 Ołbin wrocławski w XII wieku, Roczniki Dziejów Społecznych i Gospodarczych, t. 20, s. 69-103. 
1962 Taberny plockie na przełomie XI i XII wieku. W sprawie zakresu obrotu towarowo-pieniężnego, Przegląd Historyczny, t. 53, z. 4, s. 731-744.

2005 Opuscula medievistica. Studia nad historia społeczna Polski wczesnopiastowskiej, Warszawa.

Trzecieski M.

2011 Przestrzeń publiczna średniowiecznego Płocka jako przedmiot badań archeologa, [w:] Ulica, plac i cmentarz w publicznej przestrzeni średniowiecznego $i$ wczesnonowożytnego miasta Europy Środkowej, Wr.Ant. 13, red. S. Krabach, J. Piekalski, K. Wachowski, Wrocław, s. 63-75.

Urkunden und erzählende

1970 Urkunden und erzählende Quellen zur deutschen Ostsiedlung im Mittelalter, cz. 2, red. H. Helbig, L. Weinrich, Darmstadt.

Urzędnicy kujawscy i dobrzyńscy

2014 Urzędnicy kujawscy i dobrzyńscy XII-XV wieku. Spisy, oprac. J. Bieniak, S. Szybkowski, Urzędnicy dawnej Rzeczypospolitej XII-XVIII wieku, t. 6, z. 1, red. A. Gąsiorowski, Kórnik.

Vauchez A.

2001 Zwrot duszpasterski w Kościele na Zachodzie, [w:] Historia chrześcijaństwa: religia, kultura, polityka, t. 5: Ekspansja Kościoła rzymskiego 1054-1274, red. A. Vauchez, Warszawa, s. 611-634.

Warężak J.

1929 Rozwój uposażenia arcybiskupa gnieźnieńskiego w średniowieczu z uwzględnieniem stosunków gospodarczych $w X I V i X V w$., Lwów.

Wawrzyniak P.

1999 Odkrycie reliktów muru obronnego z czasów biskupa Jana Lubrańskiego na Ostrowie Tumskim w Poznaniu, [w:] Jan Lubrański i jego dzieło, KMP, nr 2/1999, s. 136-139.

Wczesnośredniowieczny Plock

2002 Wczesnośredniowieczny Płock, red. A. Gołembnik, Warszawa.

Wędzki A.

1980 Włocławek, [w:] Słownik starożytności słowiańskich, t. 6: $T-W$, red. G. Labuda, Z. Steiber, Wrocław, s. 525-527.

1995 Rozwój Gniezna w późnym średniowieczu (wiek XIII-XV), [w:] Gniezno pierwsza stolica Polski, miasto świętego Wojciecha. Katalog wystawy, red. M. Wrońska-Idziak, M. Zielińska, Gniezno, s. 27-43.

Widawski J.

1973 Miejskie mury obronne w państwie polskim do poczatku XV wieku, Warszawa. Wiesiołowski J.

2005 Kultura literacka, szkolna i dworska trzynastowiecznego Poznania, [w:] Civitas Posnaniensis, s. 193-206.

2006 Kościót i osada Święty Marcin w średniowieczu i okresie staropolskim, [w:] Święty Marcin, KMP, nr 1/2006, s. 7-48. 
Włocławek. Dzieje

1999 Włocławek. Dzieje miasta, red. J. Staszewski, t. 1: Od początków do 1918 roku, Włocławek.

Wojda L.

1993 Włocławek, Włocławek.

1995 Zamek we Włocławku na tle średniowiecznego miasta, [w:] Stolica i region. Włocławek i jego dzieje na tle przemian Kujaw i ziemi dobrzyńskiej, red. O. Krut-Horonziak, L. Kajzer, Włocławek, s. 123-135.

Wołosz A. K. F.

1998 Romańska architektura kościoła p.w. św. Dominika w Płocku, Mazowsze, t. 11, s. 89-120.

Wółkiewicz E.

2008 Patrimonium sancti Iohannis. U początków władztwa biskupiego w ziemi otmuchowskiej, [w:] Milicz, s. 225-234.

2010 Curia episcopalis. Organizacja rezydencji biskupów wrocławskich w późnym średniowieczu, [w:] Dom, majątek, klient, stuga. Manifestacja pozycji elit w przestrzeni materialnej i społecznej (XIII-XIX wiek), red. M. Pauk, M. Saczyńska, Warszawa, s. 81-110.

2013 Urzędnicy miejscy Nysy do 1618 roku, Toruń.

2014 Kościól i jego wierni. Struktury kościelne i formy pobożności w średniowiecznej Nysie, Kraków.

Wroniszewski J.

2001 Szlachta ziemi sandomierskiej w średniowieczu. Zagadnienia społeczne i gospodarcze, Poznań-Wrocław.

Wünsch T.

2002 Territorienbildung zwischen Polen, Böhmen und dem deutschen Reich: Das Breslauer Bistumsland vom 12. bis 16. Jahrhundert, [w:] Geschichte des christlichen Lebens im schlesischen Raum, red. J. Köhler, R. Bendel, Münster, s. 199-264.

Wysokiński L., Gołembik A.

2011 Budowa geologiczna rejonu skarpy płockiej, jej geomorfologia i topografia, [w:] Płock, s. 39-52.

Zbiór dokumentów

1975 Zbiór dokumentów i listów miasta Płocka, t. 1: 1065-1495, wyd. S. M. Szacherska, Warszawa.

Zbiór ogólny

1919 Zbiór ogólny przywilejów i spominków mazowieckich, wyd. J. K. Kochanowski, Warszawa.

Zielińska-Melkowska K.

1986 Przywilej chetmiński 1233 i 1251, Toruń.

Ziółkowska H.

2004 Czas powstania i osoba fundatora tzw. Zamku Przemysła w Poznaniu, [w:] Zamek książat, królów, starostów, KMP, nr 4/2004, s. 27-38. 
Zwolińska J.

1969 Pultusk $w$ średniowieczu, [w:] Pultusk. Studia i materiały z dziejów miasta i regionu, t. 1, red. J. Antoniewicz, A. Gieysztor, S. Kotarski, Warszawa, s. $2-57$.

Żebrowski T.

2003 Sierpc w średniowieczu i XVI wieku, [w:] Dzieje Sierpca i ziemi sierpeckiej, red. M. Chudzyński, Sierpc, s. 83-100.

Žemlička J.

2014 Králoství v pohybu: Kolonizace, města a střibro v závěru přemyslivské epochy, Praha.

Żurek A.

2006 Summum Wratislaviense, Śląski Kwartalnik Historyczny Sobótka, t. 61, z. 1, s. $69-84$.

\section{POLITICAL AND SOCIAL CONDITIONS OF URBAN INCORPORATION IN POLISH TERRITORY IN THE FIRST HALF OF THE $13^{\text {TH }}$ CENTURY}

\section{Summary}

The rapid acceleration of the urbanization processes in Polish territory in the first half of the $13^{\text {th }}$ century occurred in a period when the ducal document became the means of control over land ownership, trade, and generally, the confirmation of property rights. Regarding the beginnings of urban incorporations in Poland, we have only fragmentary information in written sources that is overshadowed by their model developed in the middle of this century. Archaeological excavations showed the multi-phase nature of settlement transformations in urban centres. Due to these, we can better understand the gradual development of the incorporation model: from a colony of foreign merchants, referred to as guests (hospites), to a trade and craft municipal town. Already in the first phase of urbanization, the aspirations of dukes to seize the benefits of urbanization and the development of the monetary economy collided with ownership privileges of the Church. After the introduction of the Gregorian reforms in Poland the dependence of bishops on dukes decreased. Old bestowals that were necessary to fulfil the political tasks of the episcopate and the functioning of the liturgy became a burden. The model of an early town under German law is presented in a document designed in 1237 for the incorporation of Płock. After decades of conflict with the Church in this town, the source documentation that allows researchers to know the course of the municipality's formation survived. Similar process can be observed in other diocesan seats: Wrocław, Poznań, Gniezno, Włocławek and Krakow; apart from Włocławek, bishops' cities did not develop in other centres. The Piasts gradually removed the powers of the Church, favouring other bishops' properties and cooperating with emerging urban communes. 